\title{
REFORMISMEN OG \\ DEN DANSKE VENSTREFLØJ
}

\section{Lars Qvortrup}

\section{Indledning}

I Bredsdorff/Brinch/Hansens reformismeartikel ${ }^{1}$ er det i kritikken af den »socialhistoriske « tendens blevet eksemplificeret, at den »socialistiske videnskab « ikke automatisk er en videnskab for en revolutionær arbejderbevægelse.

Dette er - hvis man skal tro den venstrekommunistiske traditions udsagn snarere reglen end undtagelsen. »Vi er teoretikerne, vi vidste på forhånd, hvad der ville ske, og nu er det sket. Og fordi vi vidste det hele på forhånd og fortalte jer det, så skal i lytte til os. Ligesom vi lavede teorien førend krisen, vil vi nu lave den teori, der fører $u d$ af krisen « - sådan, påstår Mattick, siger de »revolutionære « akademikere i realiteten. Og han fortsætter advarende: »Det er en meget farlig overenskomst, for lige pludselig begynder teoretikerne, de folk som har en forudfattet idé, at forsøge på at handle i stedet for arbejderklassen; de vil fors $\emptyset$ ge at indprente den deres egne videnskabelige begreber, at give den en strategi. Og indtil nu har vi kun set at denne intelligens, som giver arbejderklassen dens strategier, altid kun har givet arbe-

1. Nils Bredsdorff/Jens Brinch/Leif Hansen: »Arbejderbevægelse og kapitalisme« In: Kurasje nr. 21 Kbh. 1979. (Herefter: BBH). 
jderklassen en strategi, der var i intelligensen som en socialgruppe's egen specifikke interesse. $\ll^{2}$

Hvad er nu årsagen til den teoretiske elendighed, som BBH i kritikken af den socialhistoriske tendens fremdrager et eksempel på? Her er BBH ikke meget oplysende: ét sted skrives der, at »klassealliancebegrebet (...) i sine gevandter af konkrethistorisk detailrigdom virker legitimerende og fremmende på den hovedkulse flugt væk fra de sidste 10 års indsigter i den marxske videnskab. ${ }^{3}$ Det er en dårlig tautologi: Flugten fra den marxske videnskab legitimeres v.hj. af videnskab, der er flygtet væk fra den marxske videnskab! Et andet sted får vi det bud, at når »socialhistorikerne « bekæmper marxisterne så fordrejende løgnagtigt skyldes det, at disse »politiske modstandere «s »arbejde er en trussel mod socialhistorikernes egne politiske mål. $\ll^{4}$ Her skærpes nysgerrigheden: Hvilke politiske mål har »de«, hvilke har »marxisterne«, og hvorfor er de sidstes videnskab legitimationsnedbrydende for de førstes politik? Svaret får vi desværre ikke.

I det følgende vil jeg forsøge at fremdrage nogle af de sammenhænge mellem tendenser i den »socialistiske videnskab « og den danske venstrefløj, som BBH kun postulerer eksitensen af; det betyder at artiklen snarere er situationsbeskrivende, dvs. peger på nogle elementer i den komplekse, konkrete totalitet, der tilsyneladende hænger sammen, end egentlig forklarende. Herunder vil jeg påvise, at venstrefløjens reformisme-bestemmelser bl.a. har den funktion at legitimere en »overenskomst « mellem venstrefløj og arbejderklasse af netop den type, som Mattick skildrer: Hvor venstrefløjen begynder at fungere handlingsanvisende for arbejderklassen. Og jeg vil vise, at konsekvenserne også ligner dem, som Mattick fremdrager: Et eksempel er manuduktion fra venstrefløjen af ikke-revolutionære kampformer (parlamentarisme) og kampmål (statskapitalisme); et andet er kontaktsøgende opportunistisk snakken den kapitalistiske arbejderbevægelse efter munden med alle slags revisioner af den marxske teori til følge. Der vil herunder blive rig lejlighed til at berøre et sidste mål med artiklen: at påvise reformismekritikkens (af den BBHske type) fortsatte aktualitet - også for den proklamerede socialistiske venstrefløj.

2. Paul Mattick. I diskussionen mellem ham og Elmar Altvater i »Metodiske/teoretiske problemer omkring empiriske analyser af profitatefaldet. Den nuværende krise og den politiske strategi.«In: Kurasje $n r .12$, november 1975. s. 72f. Her og fremover er understregningerne i citaterne mine.

3. BBH, op.cit. I del.

4. Ibid. II, 1. 


\section{Resumé af kritikken af den socialhistoriske tendens}

$\mathrm{BBH}$ fastslår, at den socialhistoriske tendens er videnskabeligt dårlig: Den er plat empirisme og dens centrale begreber er sjuskede og uklare. ${ }^{5}$ Hermed bliver den fænomen-registrerende - den kan konstatere »at«, men ikke »hvad der er dynamikken « for fænomenerne. ${ }^{6}$

Men når den virkelige dynamik er udeladt, må der indføres en erstatning. Hertil har den socialhistoriske tendens to forslag:

1. Den rationelle kalkulation: Når kapitalisme-udviklingen ikke begribes ud fra en forståelse af kapitalen som den stadige reproduktion og udvikling af klasserne og klasse-relationerne - dette som den almene bestemmelse, inden for hvilken historien må forstås som relationer i og udvikling af den uddiferentierede samfundsmæssige totalitet - må der indsættes en erstatningsdynamik, nemlig den uddifferentierede samfundsmæssige totalitets relationer og udvikling som årsag til og derfor forklaring på sig selv: Klassekamp ogalliancer som gruppe- og magtsociologi. Denne »forklaring « forudsætter, at klasserne skulle være i stand til at tage bestik af den til enhver tid foreliggende situation for - ud fra muligheder og mål - at bestemme sig for næste rundes udfald/alliancer/etc: De skal kunne kalkulere. At denne kalkulation uden for store åbenlyse selvmodsigelser i fremstillingen kan gengives som og bliver gengivet som rationel skyldes at samfundet, som det her fremstilles, er rationelt: Det består - som i den borgerlige strukturalisme - af nogle grupper, som hver er udstyret med en vis slagkraft og nogle veldefinerede mål samfundsmæssigt betinget irrationalitet er udelukket! »De samfundsmæssige klasser forsynes med evnen til »historisk rationel« kalkulation, til som samfundsmæssige væsener på ethvert tidspunkt at veje fordele og ulemper ved en bestemt politik/strategi. « ${ }^{7}$

2. Organisations-idealisme: Endnu plattere er det andet forslag til erstatnings-dynamik: Organisationernes udviklings-determinerende kraft. »Dynamikken og vitaliteten i kapitalismen er blevet til reformismens integrationsevne og statspolitikkens succes som langsigtet politikplanlægning eller strategi. $\ll^{8}$ Det klareste eksempel på denne variant leverer nok Torben Hviid Nielsen, der i SoPo nr. 4 giver Socialdemokratiet æren/skylden for

\footnotetext{
5. Ibid. I del.

6. Ibid. I del.

7. Ibid. I del.

8. Ibid. I del.
} 
intet mindre end den nyere kapitalisme og dens nuværende krise! Denne form for historieskrivning tilspidses til en fremstilling af reformismen som en slags »borgerskabets ideologiske krigsførelse«: reformismen er - i dens forskellige fasetyper - betinget af borgerskabets indpodning af handlingsrationaler i arbejderbevægelsen v.hj.af professionelle ideologer (Keynes, Max Weber). ${ }^{9}$

9. Således skriver han, at den nuværende krise »ikke kun er en indsnævring af reformmarginen pga. den faldende profitabilitet« mv. »Den nuværende krise er osse en konsekvens af den »vellykkede« socialdemokratiske politik siden krigens afslutning ...« Torben Hviid Nielsen: »Socialdemokratiets krise - velfærdssocialismens fallit.« In: Socialistisk Politik nr. 4 Århus oktober 1976, s. 17. Se også: Torben Hviid Nielsen: Borgerskabets reformer og marxismen. Århus 1977.

Det bør dog fremhæves, at de nævnte værker indgår i en teorihistorisk sammenhæng, nemlig som en (over)reaktion på kapitallogikken. Kritikken af denne kan jeg tilslutte mig, og det skal anføres, at den også rammer BBH (Jvf. diskussionen af problemstillingen i Torben Hviid Nielsen: »En replik med lidt spredt fægtning «, in: Nordisk Forum $n r$. 18, Roskilde 1978. Indledningen til denne artikel kan læses som en ex ante kritik af BBH).

At $\mathrm{BBH}$ træffes af kritikken kommer indirekte til udtryk $\mathrm{i}$, at artiklen $\mathrm{i}$ sin kritik ikke reflekterer den nævnte teorihistoriske sammenhæng: Dens kritik af Hviid Nielsen er abstrakt.

Direkte kommer det til udtryk i artiklens modsætning mellem intentionelt at fremhæve at »Kapitalen er ikke en ting, men en social relation, kapitalens akkumulation er ikke en $\emptyset$ konomisk proces, men en social proces, og analysen af de almene former er derfor en analyse af de samfundsmæssige og ikke kun økonomiske processer ...« (s. 34) co. den reelle revenuekildebestemmelse. For det første er denne bestemmelse for generel: den svarer ikke i specificitet til de fænomener, der skal forklares. For det andet er den efter min mening fejlagtig: Bevidsthedsbestemmelsen foretages - på trods af alle de programmatisk rigtige formuleringer - som en slags »upraktisk bevidsthedssubsumtion«. Der opereres med en art underlaggelsesproces under en bevidsthedsform, hvilket f.eks. kommer til eksplicit udtryk når forfatterne mener at revenuekildebestemmelsen »er ramme for de forståelsesformer og indhold, som de samfundsmæssige processer kan anskues i.« (II, 2) Der oprereres med et indviklet system af »kinesiske æsker«, hvor der dels optræder en »ramme« for »forståelsesformer og - indhold «, og dels individerne som »subjekter«, der har en egoistisk interesse, »der udelukkende angår optimal udnyttelse af egen ejendom med henblik på højere revenueudvinding « (II, 3). Herved opstilles der en dualisme: På den ene side en uafhængigt af den praktiske væren eksisterende tingslig ramme, på den anden side - inden for denne ramme - de samfundsmæssigt interagerende individer. Herved reproducerer analysen den fordrejning, som den skulle gennemtrænge, jvf. f.eks. den programmatiske bemærkning II, 3: »Værdibevægelsens tingslige sammenhænge er (...) et samfundsmæssigt forhold mellem produktionsagenterne, der blot udtrykker sig i to forskellige - overfor hinanden tilsyneladende selvstændige - former, nemlig som relationer mellem ting og relationer mellem personer.«

Man må således kræve af analysen, at bevidsthedsformen ikke er en på forhånd given forudsætning for - »forståelsesramme «for-de samfundsmæssige processer, men netop sættes i de samfundsmæssige procesformer, som former for bevidst væren. Som BBH skriver er »kapitalen (...) ikke en ting og den kapitalistiske produktions- og reproduktionsproces er ikke blot $\varnothing$ konomi. Men kapitalen fremtræder som en ting, som producerede produktionsmidler, som samfundets individer står i et bestemt forhold til, som arbejder eller ejer.« (II, 2). Analysen skal altså bestemme kapitalen som social relations- og procesform, der fremtrader 


\section{Krisen og »venstrefløjens isolation«}

Meget tidligt i »det nye venstre«s historie opstod den tese, at venstrefløjen var isoleret fra arbejderklassen, og at dette var årsag til venstrefløjens problemer.

Sådan som tesen blev fremlagt var den imidlertid historieløs, dvs. forkert: Enten forvekslede den den (eksisterende) kapitalistiske arbejderbevægelse med en (ikke-eksisterende) proletarisk arbejderbevægelse. Heraf opstod en række misforståelser: Man mente at måtte forbinde sig med arbejderbevægelsen for at lave socialistisk videnskab - og glemte at den arbejderbevægelse, man ville forbinde sig med ikke var revolutionær. Man mente at arbejderbevægelsen måtte være interesseret i socialistisk videnskab (og at barriererne først og fremmest var af didaktisk art) - og glemte at den uinteresserede arbejderbevægelse var uinteresseret fordi den var reformistisk. Eller også universaliserede den den herskende elendige tilstand: Arbejderbe-

tingsligt. Denne dobbelthed må analysen have fat på. Hvis den blot analyserer kapitalen som socialt forhold og social udvikling, så banaliserer den den til klassekamps-sociologi. Hvis den analyserer kapitalen og kapitalakkumulationen som automatisk processerende ting, så reproducerer den de fordrejninger, som analysen skulle gennemtrænge (dvs. kritisere analytisk).

Når analysen skal bestemme lønarbejderens samfundsmæssige bevidsthedsform må den følgelig bestemme, hvorledes kapitalen igennem de samfundsmæssige relations- og procesformer, lønarbejderen indgår i, fremtræder som automatisk processerende ting. Det er min opfattelse, at bestemmelsen af den kapitalistiske lønarbejders bevidste væren skal foretages gennem en bestemmelse af den reproduktive totalitet som arbejderen som kapitalistisk lønarbejder indgår i: dvs. gennem bestemmelse af formen for det produktive konsum af arbejdskraft i produktionsprocessen, af formen for det individuelle konsum, dvs. reproduktionen af arbejdskraft i privatsfæren, og af formen for salget af arbejdskraft. I disse grundbestemmelser af den kapitalistiske lønarbejders samfundsmæssige væren fremgår bestemte relations- og procesformer - former for bevidst væren - som implicerer bestemte former for bevidsthed. Det er min opfattelse at disse grundformer kan sammenfattes i en helhed, som man kunne kalde den kapitalistiske lønarbejders handlingsrationale. Endelig kan det formodes, at institutionaliseringen af denne bestemmelse udgør grundbestemmelsen af arbejderklassens kapitalistiske organisationsform - den kapitalistiske arbejderorganisering.

Først på grundlag af en sådan bestemmelse af den kapitalistiske arbejderbevægelse som sådan er det muligt at specificere analysen - dels f.eks. i refleksioner over delingen af arbejderorganiseringen i fagforening og parti, dels i refleksioner over denne bestemmelses kommen til sit begreb i og med almengørelsen af lønarbejdet og gennemsættelsen af en egentlig kapitalistisk produktionsmåde. Hele denne problematik vil ikke yderligere blive taget op i denne artikel; den er forsøgt udfoldet i skriftet »Den kapitalistiske arbejderbevægelse« af Peter Bundesen/Filip Kruse/Lars Qvortrup/Tove Rasmussen. I $\emptyset$ vrigt udspringer den nærværende artikel af diskussionerne omkring arbejdet med pågældende skrift. 
vægelsen blev én gang for alle frakendt revolutionære potentialer. I så fald var det nærliggende for »det nye venstre « at installere sig i den ledigtblevne revolutionære rolle.

Tesen var således i begge udgaver forkert: Den socialistiske venstrefløjs problemer skyldtes ikke »isolationen fra en revolutionær arbejderbevægelse«, thi den eksisterende arbejderbevægelse er en kapitalistisk arbejderbevægelse, dvs. den er etableret inden for rammerne af og fungerer i overensstemmelse med det borgerlige samfunds - vel at mærke historisk dynamiske - reproduktionslogik. ${ }^{10}$ Men omvendt er det fejlagtigt at slutte, at fordi arbejderbevægelsen i dag ikke er revolutionær, så har den for stedse fortabt denne dens historiske mission.

Denne »isolerethed « var ikke ny, men har været den akademiske venstrefløjs skæbne siden de europæiske revolutioners nederlag i 1920-erne. Umiddelbart efter 1 . verdenskrig var der en udbredt forventning om, at den socialistiske verdensrevolution stod for døren. Den russiske revolution var gennemført i 1917 og fremstod endnu som en socialistisk revolution. Mange steder i Vesteuropa var der i forlængelse af 1. verdenskrig livskraftige proletariske bevægelser under udvikling. Således stod Tyskland tilsyneladende på tærsklen til socialismen efter revolutionen i november 1918, og noget tilsvarende gjaldt - i større eller mindre målestok - for Østrig og Ungarn, visse Balkanlande og Italien.

I begyndelsen af 1920-erne var disse bevægelser imidlertid nedkæmpet. I Tyskland allierede Socialdemokratiet sig med de borgerlige partier, og denne alliance kvalte ikke alene den proletariske bevægelse; den styrkede og radikaliserede borgerskabet så meget, at det borgerlige diktatur, fascismen, var det historiske resultat.

Göran Therborn beskriver situationen for den akademiske venstrefløj, eksemplificeret ved Frankfurterskolen, således: »Frankfurterskolens teoretikere (...) nåede intellektuel modenhed i en periode, der prægedes af arbejderklassens internationale nederlag, og de afsnøredes fra arbejderklassen af den nazistiske kontrarevolution. (...) ... det (var) en heftig reaktion mod den kapitalistiske undertrykkelse og den kapitalistiske ideologis hykleriske fornægtelse af denne undertrykkelse, som var årsag til deres indtræden i den revolutionære lejr. Reaktionen tog form af en direkte fordømmelse af alle den borgerlige ideologis patentmediciner og især af den $\varnothing$ konomiske ideologi om det frie og lige bytte. Men netop som den indtog disse positioner, antog den kapitalistiske system i og med den nazistiske magtovertagelse en politisk form af hidtil ukendt monstrøsitet. (...) Resultatet blev at den

10. Jvf. leder i Kurasje nr. 12 op.cit. s. 3. 
indledende attitude af reaktion blev fastfrosset i stedet for at blive udviklet til en videnskabelig analyse og deltagelse $\mathrm{i}$ den revolutionære politiske praksis. $\ll^{11}$

Vigtigst for Frankfurterskolens videnskabelige udvikling var det nok, at den tyske revolution ikke primært - som det ellers bliver fremstillet i diverse efterrationaliseringer af begivenhederne - blev »nedkæmpet « af Socialdemokratiet og borgerskabet. Den tyske revolution var fra starten en politisk revolution, som angreb og ændrede det statslige og kommunale politiske og administrative apparat, men ikke det kapitalistiske lønarbejde. Imidlertid var midlerne særdeles radikale, hvorfor forløbet fremstod sådan, at arbejderklassen stod med det socialistiske samfund i hænderne, men - under større eller mindre moralsk og bogstaveligt pres fra Socialdemokratiet - af sig selv opgav det revolutionære forehavende, og i løbet af nogle år under stiltiende accept gled ind under først Weimarrepublikkens restaurerede borgerlige samfund og derefter nazismens borgerlige diktatur.

For den kritiske intelligens fremstod forløbet på den måde, at arbejderne lod sig bedøve: Den sansede ikke den så nærliggende socialistiske utopi, men indhylledes i det borgerlige samfunds skin-lykke. Kun den lille akademiske venstrefløj stod tilbage med en klar erkendelse af situationen, men uden mulighed for at handle. Et patetisk billede af denne misere finder man i Horkheimer og Adornos »Oplysningens dialektik $«,{ }^{12}$ hvor de bl.a. skildrer Odysseus's rejse fra Troja til Athen. Undervejs passerer hans skib sirenernes land. For ikke at blive draget af - og dermed gå til grunde p.gr.af - sirenernes lokkesang lader Odysseus besætningens ører lukke med voks. Således ror den intetanende forbi. Og for ikke selv at gå til grunde lader Odysseus sig surre fast til masten. Således er massernes sanser tillukket for den revolutionære ur-sandhed, og selv den kritiske videnskabsmand, som kan sanse denne sandhed, er i smertelig viden om forholdene afskåret fra at realisere den.

I forbindelse med studenterbevægelsens fremmarch i slutningen af 1960erne tydeliggjordes denne situation påny (omend den også havde sat sit præg på den mellemliggende periodes kulturradikale og modernistiske kamp for mennesket mod atomvåben, »forbrugerisme«, »popmusik«, »reklameindustri« etc. etc.), at den akademiske venstrefløj stod alene med sin kritik af det borgerlige samfund over for en arbejderbevægelse, der altovervejende

11. Göran Therborn: Frankfurtskolan. Till kritiken av den kritiske teorin. Göteborg 1976. s. $50 \mathrm{f}$.

12. Horkheimer og Adorno: Oplysningens dialektik. Skrevet under 2. verdenskrig. Udkom 1947 på dansk 1972 . 
var socialdemokratisk, og hvis reformisme - for en lang tid - rimeliggjordes af en tilsyneladende stabiliseret kapitalistisk akkumulation, af en statslig fornuftiggørelse af det borgerlige samfund og af tydelige kvantitative forbedringer af lønarbejdernes reproduktionsniveau. Denne situation med visse uforandrede grundelementer afføder dels umiddelbart nærliggende oplevelseskategorier og politiske aktivitetsrationaler for den akademiske venstrefløj, dels får den denne venstrefløjs teoretiske og praktiske væren (der som sagt hele tiden påny er betinget af situationens grundelementer) til at fremtræde som betinget af en lang, kontinuitetspræget udviklingshistorie. $^{13}$

Traditionen udvikledes til en revolutionsteori, hvis kerne udgjordes af »det nye venstre «. Den kendteste fortaler for opfattelsen var nok Marcuse, som netop havde rødder i den klassiske Frankfurterskole. Arbejderklassens sanser var tillukket, stoppet til af den udviklede kapitalismes overflod: »Den udbredte ikke-revolutionære, eller ligefrem anti-revolutionære bevidsthed hos hovedparten af arbejderklassen er påfaldende tydelig. (...) Integreringen af den største del af arbejderklassen i det kapitalistiske samfund er ikke blot et overfladisk fænomen, det har rødder i selve infrastrukturen, i monopolkapitalismens politiske $\varnothing$ konomi, de goder, der bliver tildelt metropolernes arbejderklasse i form af merprofitter, nykolonialistisk udbytning, militærudgifter $\varnothing \mathrm{g}$ kæmpemæssig statsstøtte til industrien.

(...) Kapitalen (...) gør hele mennesket - både hjerne og sanser - til genstand for administration, tilpasset til at producere og reproducere ikke blot systemets mål, men også dets værdinormer og løfter, dets ideologiske himmerige. ${ }^{14}$

Kun de unge intellektuelle, hvis sanser er skærpet af de akademiske sysler og hvis kritiske potentialer ikke er korrumperet, kan gennemtrænge »forbrugersamfundets fetichisme «: »Overvægten af intellektuelle (...) inden for bevægelsen (»det nye venstre « kalder Marcuse den, LQ) er da også tydelig. Det er måske et udtryk for den voksende anvendelse af intellektuelle af alle slags inden for både infrastrukturen og i den ideologiske sektor af den $\varnothing$ konomiske og politiske proces. Hertil kommer, at for så vidt som frigørelse forudsætter udvikling af en radikalt anderledes bevidsthed (en veritabel kontra-bevidsthed), der er i stand til at gennembryde forbrugersamfundets fetichisme, så forudsætter det en viden og en sanselighed, som den bestående

13. Som det vil fremgå, argumenterer nærværende artikel også tit på dette overfladiske oplevelsesplan - hvor samfundsmæssigt producerede og reproducerede tendenser aflæses som »fremskridt «, »forfald « etc., dvs. ikke sættes i forhold til den nærværende totalitet, tendenserne eksisterer i så meget som til bevægelsens historiske tradition.

14. Marcuse: Kontrarevolution og venstrefløj. Udkom 1972 på dansk i 1974. s. 15 og 24. 
orden, gennem sit klassebestemte uddannelsessystem, blokerer adgangen til for hovedparten af befolkningen. ${ }^{14 a} »$ Det nye venstre « repræsenterer - med udtryk som senere er blevet til nøglebegreber - den »ydre« og »indre« natur: »Hvad indebærer naturens frigørelse som middel til menneskets frigørelse? Denne forestilling refererer for det første til menneskenaturen, menneskets primære sanser som grundlag for dets rationalitet og erfaring, og for det andet den omgivende natur, menneskets eksistentielle miljø, den »kamp med naturen «, hvorigennem det former sit samfund. « ${ }^{14 \mathrm{~b}}$

Det er nærliggende at installere dette »nye venstre « som avantgarde for den bedøvede arbejderklasse: »Den eneste modstandskraft ligger i udviklingen af en effektivt organiseret radikal venstrefløj, der kan påtage sig den enorme opgave med den politiske skoling og bortjage den falske og lemlæstede bevidsthed hos folket, så de selv kan opleve deres egen situation og afskaffelsen af den som et vitalt behov, og så de kan forstå fremgangsmåderne til deres egen frigørelse. $\ll^{14 c}$

Denne situation - og den bestemte fortolkning af den - prægede selvfølgelig venstrefløjens teoretiske og praktiske strategi. ${ }^{15}$ Teoretisk søgte men dels at forklare den selvoplevede $» \mathrm{kl} \varnothing \mathrm{ft} \ll,{ }^{16}$ dels at legitimere en revo-

14a. Ibid. s. 44.

14b. Ibid. s. 74 .

14c. Ibid s. 40.

15. Ret hurtigt fik den sine »selvstændige« danske formuleringer. Således blev det fremhævet, at netop studenternes »klassemæssige baggrund og subjektive konstituering gør dem særlige modtagelige for den samfundsmæssige undertrykkelse og gør dem særlig egnede til at erkende denne undertrykkelse og udvikle former for en virkelig rebellering mod den.« Boj Bro: Studenterbevagelsen - illusion og virkelighed. Fagtryk 36. u.å. s. 5) Arbejderne derimod har mistet deres »revolutionære sensibilitet «: »Den manglende sensibilitet over for undertrykkelsen i lønarbejderklassens organisationer (...) lader sig (...) forstå ud fra deres hverdags strukturelle bestemthed: direkte underordnet autoritære og materielle herredømmeforhold« (Ibid. s. 5). (Jvf. også Ib Thiersen: »Kapitalismens udviklingstendenser« in: Teori og praksis nr. 5, f.eks. s. 145). Og dette var bare startskuddet til en stedse mere dominerende »socialisationsteoretisk « interesse, i hvilken man typisk identificerer udbytning med undertrykkelse og dermed gør undertrykkelsens konflikt mellem kapital og individ til den afgørende konfliktform i kapitalismen. Modstanden mod kapitalismen udspringer af det overvintrede »ægte liv«, for så vidt det ikke er knust under den kapitalistiske produktionsmåde.

16. I denne artikel eksemplificerer jeg forklaringstypen v.hj.af reformismeteorien. Men se også socialisationsteorien, hvis udgangspunkt netop er den historieløse konception af situationen: »Kløften« eksisterer ikke fordi arbejderbevægelsen som kapitalistisk arbejderbevægelse $m a ̊$ være reformistisk, men fordi den i sin »natur « revolutionære arbejderbevægelse er blevet gjort reformistisk: Erkendelsesinteressen er med en central formulering blevet udtrykt således: »Spørgsmålet: Hvorfor lader arbejderne sig udbytte må (...) stilles mere præcist: hvorfor protesterer arbejderne ikke mod kapitalforholdet. Thi kapitalens reproduktion beror kun på den kendsgerning, at de lader sig udbytte - det vil sige: en afgørende 'subjektiv faktor' er bærer af den kapitalistiske reproduktionsproces ...« (Krahl: Konstitution und Klassenkampf, Frankfurt a.M. 1971 s. 76). 
lutionær fortrinsstilling for venstrefløjen, hvilket bl.a. resulterede i tydelige revisionistiske tendenser i omgangen med den marxske teori. Praktisk søgte man at overskride »kløften «, enten ved avantgardistisk at tildele sig selv rollen som historiens lokomotiv eller ved opportunistisk at anbefale

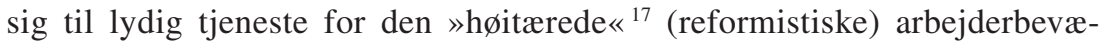
gelse.

Disse tendenser fra »det nye venstre «s første fase er ikke blevet dementeret af de seneste års krise, men snarere forstærket. I takt med kriseudviklingen fra 1973 er studenterbevægelsen - og dermed store dele af venstrefløjen løbet ind i voksende problemer - problemer som ikke forklarer situationen, men som er konkrete udtryk for tilstanden i et kriseramt kapitalistisk samfund med en dominerende socialdemokratisk arbejderbevægelse: Studiebetingelserne er blevet forværret, levevilkårene forringet, og den forventede radikalisering af arbejderbevægelsen i takt med krisen er udeblevet. Den umiddelbare konsekvens er, at »isolationstilstanden « opleves i forstærket grad, og reaktionen er for det første, at reformismen gøres til et teoretisk og praktisk hovedproblem og for det andet, at man med stigende styrke forsøger at betvinge historien organisatorisk og taktisk, enten ved som lederskab at anvise arbejderklassen den »rigtige « vej (dvs. den vej, som intelligensfortroppen anviser), eller ved ukritisk og opportunistisk at kaste sig i armene på den reformistiske arbejderbevægelse.

\section{Venstrefløjen og Socialdemokratiet}

Den traditionelle opfattelse af Socialdemokratiet går ud på, at SD er et parti, der engang var socialistisk, men som senere er degeneret til et reformistisk parti. Ergo, konkluderes der, er SD stadig i sin kerne (og denne kerne opfattes som regel som SD's »basis«) socialistisk, det er bare i den politiske hverdag skredet af sporet.

Den klassiske fremstilling af denne afsporing finder man hos $I b$ N $\phi$ rlund. ${ }^{18}$ Ifølge ham skete ulykken omkring septemberforliget i 1899, selvom grunden var lagt allerede tidligere: »Den naturlige trang til at opnå håndgribelige resultater tilligemed (...) svagheder i den socialistiske forståelse ...« gav

17. Jvf. H.-J. Schanz: Antikritik. Århus 1977. s. 17.

18. Ib Nørlund: Det knager i samfundets fuger og bånd. København 1972. 
baggrund for tendenser til at at »... indordne de faglige organisationer under den bestående samfundsorden og kapitalisternes klasseherred $\varnothing$ mme. $^{19}$ Dette forstod kapitalen at udnytte! Dens »nye taktik « var »at binde arbejderne gennem organisationernes borgerliggjorte ledere.« Arbejdertoppens svagheder og kapitalisternes snuhed løb sammen i 1899's storkonflikt: Arbejderlederne ville jo nå »håndgribelige resultater« og havde ikke den teoretiske ballast til at overskue situationen. Og kapitalistklassen vidste hvad den ville. »Septemberforliget blev på denne måde et afgørende skridt for reformismens sejr i dansk arbejderbevægelse. Det indledte den proces, som forvandlede ikke blot DSF, men også det socialdemokratiske parti til social hovedstøtte for det danske bourgeoisi. $\ll^{20}$

Når SD således - inderst inde - stadig er socialistisk, men blot er skredet i højre grøft, gælder det for venstrefløjen om at løfte partiet på det rette spor igen. Et tydeligt eksempel på den politiske konsekvens af en sådan opfattelse finder man i SF, som igen og igen konstaterer, at SD ikke er socialistisk, og lige så ofte trøster sig med, at inderst inde må der være en rest tilbage, som venstrefløjen skal tvinge frem. Som så ofte før kunne Gert Petersen d. 10. august 1977 - dvs. op til SD's kongres - med løftet pegefinger konstatere: »Vi skal ikke bebrejde Socialdemokratiet, at det prøver at manøvrere sig igennem (...) Nej, det vi bebrejder Socialdemokratiet er noget andet og noget helt præcist: at det under sin uundgåelige manøvrering er holdt op med at arbejde på og overbevise et flertal om nødvendigheden af socialistiske midler - altså at opstille et socialistisk alternativ, slå på tromme for det, mobilisere for det. $\ll^{21}-$ Og allerede $1 \frac{1}{2} 2$ måned efter er den - som lige så ofte før - ved at gå på Gert Petersen; bebrejdelserne synes at have hjulpet: »Med det socialdemokratiske principprogram af 1961 blev 1913-programmets socialistiske målsætning udskiftet med nogle ord om »tilpasning af ejendomsretten«. Nu, i 1977, er man vendt tilbage til at: »Den endelige målsætning er fælleseje af produktionsmidlerne«. Socialdemokratiet er påny blevet til et socialistisk parti - i sin målsætning. «22 Straks sadler Gert P. sin Rosinante og hugger sporene i den samlede venstrefløj: »Nu må venstrefløjen være oppe på mærkerne (...) for at fremme den tøvende kritiske bevægelse der er i gang i partiets basis og »mellemlag«. (...) Ved at presse på, og især udefra (...) for at regeringen og regeringspartiet også bruger det andet flertal i det nuværende Folketing. « ${ }^{23}$

19. Ibid. s. 68 .

20. Ibid. s. 71.

21. Information d. 10/8 1977. Citeret fra Politiske Arbejdstekster nr. 11-12, Kbh. dec. 1977 s. 56.

22. Information d. 21/9 1977.

23. Ibid. 
Dette SFske sisyphos-arbejde har velsagtens bidraget til, at de helt umiddelbare illusioner om SD er bortvejet på den mere reflekterede del af venstrefløjen.

Men hvor dybe spor har det SFske lærestykke sat? Tilsyneladende er forfaldsteorien erstattet med en sofistikeret opfattelse i stil med den, at den kapitalistiske arbejderbevægelse fungerer i overensstemmelse med det kapitalistiske samfunds reproduktionslogik - fordi den simpelt hen er en del af denne logik. Således skriver Mikael Waldorff fra VS, at grænserne for SD »afstikkes af det kapitalistiske samfunds overlevelsesmulighed og stabilitet, inden for hvilket reformismen fors $\emptyset$ ger at varetage arbejderklassens interesser.« Derfor er forfaldsteorien forkert: »SDs politik er (...) en række historisk forskellige udgaver af den samme grundliggende målsætning og strategi. $\ll^{24}$

Imidlertid er der nogle alvorlige sprækker i Waldorffs analyse. Tilsyneladende er det kun SD som parti - dvs. som organisatorisk hylster, som »partitop « - der indgår som element i den kapitalistiske reproduktionslogik. Arbejderklassen - og endog SD's »menige medlemmer « - står udenfor. Men hvorfor stemmer de så på det parti, som de kvalitativt adskiller sig fra? Af vane! Og fordi de ikke har forstået, hvad det er de giver deres stemme, ikke på konsekvenserne af det, i hvert fald: »... medlemmernes almindelige sympati for den reformistiske målsætning er en sympati uden forståelse for den virkelige konsekvens af den reformistiske strategi. $\ll^{25} \gg$ Derfor ser den socialdemokratiske arbejder heller ikke de mange overgreb fra den socialdemokratiske regering (og fagbevægelsen) som et sammenhængende udtryk for reformismen. Den opfattes som enkeltstående begivenheder, som man enten affinder sig med, fordi man kan »se nødvendigheden af det i den aktuelle situation«, eller man tager afstand fra det, men holder i $\emptyset v r i g t$ fast ved partiet, fordi det jo egentligt vil noget rigtigt! «26

Men dermed er vi jo - på trods af alle sofistikerede formuleringer - tilbage hos Ib Nørlund! Skal vi tro MW, så har SD været et såkaldt »borgerligt arbejderparti $\ll^{27}$ næsten siden starten. Og arbejderklassen har - selvom den inderst inde vidste bedre - lige så længe fundet sig i »overgreb« og stemt socialdemokratisk af - en efterhånden meget - gammel vane! Som det fremgår, mangler MW's analyse simpelt hen evne til at forklare historien.

24. Mikael Waldorff: »Socialdemokratiet - et borgerligt arbejderparti.«In: VS-Bulletin nr. 182. s. 6.

25. Mikael Waldorff: »Den socialdemokratiske reformismes modsætninger.« In: Politiske Arbejdstekster nr. 11-12 op.cit. s. 46.

26. Ibid. s. 47. Jvf. også Preben Wilhjelm, som i Information d. 22/9 1977 skrev: Der er tale om den »komplet desillusionerede socialdemokratiske arbejder, som uden tvivl var endda meget lydhør overfor venstrefløjen, før han nødtvungent valgte resignationen.«

27. Hvad det så er? Jvf. Torben Hviid Nielsen i Nordisk Forum nr. 18, op.cit. s. $49 f$. 
De strategiske konsekvenser af en opfattelse som MW's - der som sagt korrelerer med venstrefløjens selvoplevede »isolation « - er nærliggende: Det gælder for venstrefløjen om at trække arbejderbasis'en væk under SD. Det er denne funktion, som den herskende reformismeteori udspringer af og leverer legitimation til. Dette kan tilsyneladende gøres på to forskellige måder, som vi på de følgende sider skal betragte lidt nøjere: Enten kan det gøres ved en de-legitimering af SD, dvs. ved at påvise at SD slet ikke handler på den måde, som partiet burde og som arbejderne tror det gør. Eller det kan gøres ved en legitimering af venstrefløjen, dvs. ved at påvise, at venstrefløjen slet ikke er så slem, som arbejderne tror den er. Begge strategier har det klare mål, at venstrefløjen skal fortrænge SD og tilbyde sig selv i stedet for: De nye magthavere skal fortrænge de gamle!

\section{VS - avantgardistisk nøgternhed}

\section{a. »Demokratisk centralisme«}

Allerede i 1972 kunne Brückner og Krovoza om beslægtede tyske forhold (som først satte sig klart igennem i Danmark nogle år senere) konstatere, at optimismen fra slutningen af 1960-erne var blevet skuffet, og at de umiddelbare reaktioner var politisk udgrænsning - ud fra en tro på at man gennem evindelige fraktionsdannelser kunne skabe dén politiske renhed, som skulle kunne løse problemerne organisationsfetichisme - ud fra opfattelsen at blot man gjorde organisationen »handlekraftig«, dvs. centralistisk, nok, kunne man betvinge historien - m.m. Indholdsmæssigt skete der en neddæmpning af utopierne: Man kæmpede ikke længere for gennemgribende ændringer i arbejds- og livsformerne, men for ændringer af ejendomsretten til produktionsmidlerne, dvs. for en overflyttelse af styrings-institutionen fra de private kapitalister til det statslige byrokrati. Målet blev lidt efter lidt reduceret til en administrativ retfærdiggørelse og fornuftiggørelse af de - i princippet uantastede - kapitalistiske arbejds- og livsformer.

Brückners og Krovozas umiddelbare forklaring ${ }^{28}$ var, at udviklingen udtrykte en manglende befrielse af de opskruede forventninger, kombineret

28. Som udmærket indfangede nogle symptomer, men som ganske klart ikke fjernede sig fra overfladeplanet(s historie om bevægelsens »forfald«) og som yderligere svækkedes ved at levere en radikalt borgerlig og ikke en marxistisk kritik af leninismen. 
med manglende historisk bevidsthed: »Organisationen bliver til et middel til kollektiv fortrængning «, skrev de. ${ }^{29}$ Herved bliver de virkelige forhold vendt på hovedet: »De som er bukket under for rådvildhedens fristelser fremtræder nu som de sande afklarede, som de virkelige forvaltere af arbejderklassens tradition (...) Resterne (...) står tilbage med rådvildheden (og kritikken), miskrediterede af dem, der har fundet den nye gamle vej frem. $\ll^{30}$

Herudover indgår den ovennævnte opfattelse af reformismen som et afgørende element $\mathrm{i}$ den organisatoriske udvikling: For så vidt som arbejderklassen opfattes som en relativt træg masse, hvis handlinger bestemmes af den udefra kommende organisation, så er det nødvendigt med et parti, der udadtil og indadtil er handlekraftigt: Udadtil for effektivt at kunne sætte sit præg på arbejdermassen; og indadtil for at kunne holde styr på den del, som allerede har tilsluttet sig. I begge tilfælde er (demokratisk) centralisme et nøgleord.

Den avantgardistiske tendens kendes også herhjemme, mest udbredt måske i VS. Således kritiserede man i »HB-beretning til 9. kongres $\aleph^{31}$ at $»$ grundlaget for medlemmernes indsats « hidtil havde været »deres individuelle behov og interesser «. Nu skulle behov og interesser tilsyneladende fortrænges til fordel for en meget alvorligere diskussion: »Diskussionen om, hvordan et revolutionært lederskab i arbejderklassen opbygges. « Partiet skal - i forlængelse af Waldorffcitaterne ovenfor $-»$ give de reformistiske arbejderes erfaringer en retning, som fører til brud med reformismen.«32

Denne holdning har - når den som abstrakt organisationsprincip transporteres op til den udviklede, statsinterventionistiske kapitalisme ${ }^{33}$ - følgende konsekvenser: For det første at arbejderklassen opfattes som en træg masse, hvis historiske skæbne bestemmes af de eksterne politiske kræfter, der er under indflydelse af. Historieskrivning af den socialhistoriske type ${ }^{34}$ er altså nærliggende. For det andet at det, som man forsøger at påtrykke denne arbejdermasse, er det »revolutionære lederskab»s (som regel studenters og færdiguddannede akade-

29. Brückner/Krovoza: Was heisst Politisiering der Wissenschaft und was kann sie für die Sozialwissenschaften heissen? Frankfurt a.M. 1972.

30. Åge Edvardsen: upubliceret manus, Odense 1978.

31. Skrevet i slutningen af 1976.

32. Mikael Waldorff op.cit. s. 47.

33. »Marxistische Aufbauorganisation« fremhæver i bogen Demokrati og socialisme det kritisabelt uhistoriske i avertage et organisationsprincip. I bogen fremdrages »... den indholdsmæssigtpolitiske og strategiske betydning af begrebet »den demokratiske centralisme«, der for det meste (og ofte af leninister) misforstås i retning af et blot formalt organisationsprincip.« Demokrati og socialisme, Århus 1973, s. 52.

34. Jvf. BBH op.cit. 
mikeres) opfattelse og interesser. Den organisatoriske årsag er at den organisation, som skal være »slagkraftig « og fortrænge «individuelle behov og interesser «, må opbygges hierarkisk med et lederskab, der udadtil og indadtil udspyr sine erfaringer og interesser uden nogen form for feedback - andet end den, at lederskabet en dag skiftes ud med et andet lederskab, som ligner det afgående ved en tro på organisationens historiske betydning og ved en - akademisk evne til byrokratiske og verbale fraktionskampe. Problemet er - som allerede nævnt - at skulle forene den demokratiske centralisme som stor-organisatorisk erfaringsudveksling-, diskussions- og beslutningsform med det krav, at partiet skal fungere som en handlende enhed: Det resulterer hele tiden $i$ at det indre demokrati (forstået som en organisk erfaringsudvekslingsproces) tilsidesættes til fordel for slagkraften udadtil. Dels skal partiet handle helhedsmæssigt: Herved får partitoppen uundgåeligt vidtgående beføjelser. Dels skal partiet handle enhedsmæssigt: Herved bliver de lokale afdelingers selvstændige handlemuligheder beskåret. Det første betyder, at kampen om partitoppen bliver central, dvs. kan blive til mål (og »partilivet« reduceret til middel). Det sidste betyder, at den decentrale erfaringsdannelsesproces, som selvfølgelig burde ske i snæver kontakt til de lokale samfundsmæssige forhold, bliver indskrænket. Umiddelbart vil disse modsætninger nedefra opleves som byrokratiseringstendenser (particentralens båndlæggelse af handlemulighederne) og oppefra opleves som handlingslammelsestendenser (de demokratisk begrundede handlingsindskrænkninger). Under alle omstændigheder rummer disse forhold tilbøjeligheder til selvstandiggфrelse af partiet (partiet som »lejr« i samfundet), hvorved faren for at partiet udspyr erfaringer og handler efter interesser, der stammer fra partiets egen dominerende socialgruppe, er nærliggende..$^{35}$

\section{b. BBP som didaktik: kapitalistisk nøgternhed.}

Målet for VS var: delegitimering af SD. Det nok bedst kendte redskab hertil har været BBP.

\section{Hvad er BBP?}

BBP er forkortelsen for VSs Beskaeftigelses- og betalingsbalanceplan. ${ }^{36}$ Den blev fremsat af VS op til det augustforlig, som Socialdemokratiet og en række borgerlige partier lavede i 1977.

35. Jvf. Niels Ole Finnemann: »VS - et parti for det nye venstre?« In: Socialistisk Politik nr. 9, april 1978.

36. Det følgende bygger dels på det oprindelige særtryk, dels på den modificerede udgave i VS Bulletin nr. 180. 
Planen var særdeles omfattende. Den strakte sig over 4 år og omfattede følgende felter: Boligbyggeri (nybyggeri og byfornyelse), »alternative « energiforsyning, Skibsbygningsprogram, udvidelser af den offentlige sektor mht. reproduktionen af arbejdskraften (skoler, plejehjem m.v.), forbedring af muligheden for adgang til førtidspensionering og fyringsafgifter (dvs. afgifter som kapitalisten skulle betale hvis han afskedigede arbejdere). Derudover blev planen suppleret med nogle budget- og importbegrænsende foranstaltninger (f.eks. annullering af F-16 købet og skrinlæggelse af planen om opførelse af atomkraftværker).

Konsekvensberegningerne omfattede 3 punkter: beskæftigelseseffekten, de offentlige budgetter og betalingsbalancen. Planens konsekvenser var flatterende: Allerede første år fik den knap 100.000 flere i arbejde, de offentlige budgetter blev under hele planens virkeperiode reduceret med ca. 31/2 milliarder kroner og betalingsbalancen forbedret med 0,2 milliarder kroner det første år op til knap 3 milliarder kroner det sidste år. (I disse tal har jeg endog set bort fra de påklistrede budgetog importbegrænsende foranstaltninger).

Kun et par måneder efter planen var offentliggjort, fortrød VSs Hovedbestyrelse dens mest vidtrækkende punkt: fyringsafgiften. Dette punkt blev trukket ud af planen, »fordi vi mener at det skal diskuteres mere grundigt i VS«. Men tendensen i planen var stadig smuk: Op til 100.000 flere i arbejde, en reduktion af de offentlige budgetter på knap 2 milliarder kroner og en forbedring af betalingsbalancen på godt $2 \frac{1}{2} 2$ milliard kroner i planens sidste år.

I fremlæggelsen af planen blev der lagt stor vægt på kriterierne for forslagene. Det $\varnothing$ konomiske støtte til fordel for beskæftigelsen, som planen omfatter, må »ikke kunne kapitaliseres til fordel for privatpersoner eller -virksomheder «. «Beskæftigelsesforanstaltninger foreslås aldrig for beskæftigelsens egen skyld, men må tage sigte på projekter, som er i arbejderklassens interesse «. ${ }^{37}$ Planen holdt sig langt fra forslag, som implicerer »indkomstpolitiske « eller finanspolitiske lønreduktioner. Og den styrede også uden om chauvinistiske kriseløsningsforslag, dvs. forslag som løste krisen for danske arbejdere på bekostning af udenlandske (importregulering).

37. Dette interessekriterium er altså brugsværdimæssigt: Storebæltsfærger er bedre end Storebæltsbro. Alternativ energi er bedre end kerneenergi. Jens Brinch har ret $\mathrm{i}$ at dette prioriteringsprincip er særdeles uklart: «Hvorfor er det f.eks. mere rimeligt klassepolitisk set at fremme skibsbyggeri end f.eks. fodtøj, beklædning og møbelindustrien? Eller elektronik (TV og radio)? Eller fødevareproduktion? « Jens Brinch: «Offensiv krisepolitik - om beskæftigelse og betalingsbalance.« In VSR-Kommunikation nr. 20 s. 3. 
Endelig fremhævede man målet for forslagene: »de tager sigte på at formulere de krav, som arbejderklassen må tvinge igennem for at undgå at komme til at betale omkostningerne ved kapitalens krise.«

\section{BBPs »tekniske realisme»}

Ved en pressekonference i august 1977 præsenterede Steen Folke iflg. Information planen således: »Det er et teknisk- økonomisk forslag, der skal styrke kampen ude på arbejdspladserne og andre steder ... $\ll^{38}$

Iflg. BBP kan man adskille den tekniske $\varnothing$ konomi og den politiske $\varnothing$ konomi. »Når VS (...) opstiller en plan og gennem så omhyggelige konsekvensberegninger som det er muligt at foretage påviser, at den er teknisk realistisk, så ... $\ll^{39}$ En sådan forestilling om den »værdifri« økonomiske videnskab forudsætter en inddeling af det kapitalistiske samfund, som svarer til socialhistoriens implicitte opfattelse, og som reelt er socialdemokratisk: Her: den tekniske $\varnothing$ konomi. - Dér: Den politiske klassekamp.

Generelt er problemet, at når man på denne måde udtrykker sig med en »teknisk realisme«, så udtrykker man sig på den bestående videnskabs, dvs. på den umiddelbart fremtrædende, fordrejede virkeligheds vilkår. Modstanderens præmisser accepteres som »neutrale « præmisser. Forskellen mellem »dem « og »os« er herefter kun moralsk: BBP er mere arbejdervenlig, »de andre « mere kapitalvenlige. Herved har »de andre« allerede vundet den afgørende ideologiske sejr.

Mere specifikt er problemet, at det bliver planens indirekte udsagn, at den kapitalistiske $\varnothing$ konomi er teknisk, dvs. naturgivet. Herved har BBP-forfatterne viderebragt en opfattelse, som i øvrigt ligger dem fjernt: Det, der kan ændres, er det historisk-politiske, dvs. kapitalismens politiske og juridiske gevandter. Planen bestyrker altså den socialdemokratiske forveksling af reformeret kapitalisme og socialisme.

\section{Er BBPs »tekniske realisme« realistisk?}

Jeg har allerede fremdraget nogle alvorlige mangler ved BBPs begreb om »teknisk realisme«. Dog står der et afgørende spørgsmål tilbage: Kan det virkelig lade sig gøre at føre »arbejderpolitik « i BBPs forstand på de præmisser, som kapitalens »tekniske realisme« leverer. Er BBPs forslag - som jo implicit er

38. Steen Folke i Information d. 17/8 1977.

39. BBP in VS Bulletin op.cit. s. 3. 
en påstand om den progressive reformpolitiks meget vide grænser inden for kapitalismen ${ }^{40} \mathrm{og}$ derfor leverer et forsvar for en sådan politik - i realiteten holdbart?

If $\varnothing$ lge BBP er den kapitalistiske $\varnothing$ konomi en teknisk $\varnothing$ konomi, som følgelig kan udtrykkes v.hj.af en model, der kan underkastes forskellige manipulationer. »Hvis vi gør sådan, så sker der det og det ...« er filosofien bagved planens »omhyggelige « konsekvensberegninger.

Rent umiddelbart er konsekvensen, at udarbejdelsen af planer og konsekvensberegninger er skrivebordsarbejde, som kun er underlagt de matematiske reglers kontrol. Det frister som bekendt til regnskabsfusk - og BBP modstår for mig at se ikke denne fristelse.

Et af BBPs forslag lyder på en »skrinlæggelse af fast forbindelse over Storebælt». Det giver iflg. planen en besparelse på de offentlige budgetter over 4 år på 1600 mio. kr. og en forbedring af betalingsbalancen over 4 år på 470 mio. kr. Derimod har det hverken positiv eller negativ beskæftigelseseffekt.

Bagved en sådan beregning må ligge flg. argumentation: Hvis Storebæltsbroen blev bygget, så ville staten skulle betale 1600 mio. kr., og så ville »Danmark « skulle importere udenlandske produkter for 470 mio. kr. Når VS skrinlægger Storebæltsbroen er konsekvensen følgelig tilsvarende besparelser.

Hvad angår beskæftigelseseffekten ræsonneres der imidlertid på en anden måde: Storebæltsbroen beskæftiger $i$ фjeblikket ikke nogen. Ergo vil en skrinlæggelse af Storebæltsbroen ikke have nogen (negativ) beskæftigelseseffekt.

Problemet er m.a.o., at konsekvensberegningerne foretages ud fra forskellige forudsætninger (alt efter hvad der giver det bedste resultat).

Samme beregningstrick anvendes i energiforslaget: ${ }^{41}$ Her beregnes effekten for betalingsbalancen ud fra den forudsætning, at der med planen ville ske en erstatning af udenlandsk energiproduktion med dansk. Beskæftigelseseffekten bestemmes derimod under forudsætning af at der sker en energiforøgelse, dvs. at nuværende energiproduktion ikke berøres; sagt anderledes gennemføres beregningen m.h.t. beskæftigelseseffekten $u d e n$ at den negative effekt af en strukturomlægning fra den nuværende til den foreslåede energiproduktionsform indregnes.

40. Anfægtelser heraf fandtes stort set kun i fyringsforslaget, som Hovedbestyrelsen meget hurtigt trak ud af planen!

41. Energiforslaget blev fremsat i Folketinget (Beslutningsforslag B 7-10, 9. marts 1977), hvorfor der er gennemført eksplicitte og detaljerede konsekvensberegninger (bemærk at når tallene ikke helt stemmer med de tilsvarende i BBP skyldes det, at BBPs isoleringsafgift er reduceret med $30 \%$ i forhold til beslutningsforslaget). 
Endelig er der den skævhed i energiforslaget, at man sammenligner beskæftigelseseffekten af allerede etablerede energikilders drift med effekten af anlag af alternative energikilder. Derved undgår man dels at vurdere beskæftigelseseffekten når anlæggelsen er tilendebragt, dels at sammenligne med beskæftigelseseffekten af forslag til andre energiforsyningsanlæggelser, f.eks. atomkraft. ${ }^{42}$

42. De angivelige resultater af energiforslaget er:

1. Forslaget medfører en reduktion af arbejdsløsheden ved 47.000 på år.

2. Det indebærer en valutabesparelse ved planens afslutning på 3 mia. kr. pr. år, fordi forbrugerne nu køber dansk energi, ikke multinational olie.

3. De offentlige budgetter forbedres med 2 mia. kr. pr. år p.gr. af den reducerede arbejdsløshed, idet staten slipper for at betale underst $\varnothing t t e l s e$.

Lurer der intet steds i dette kapitalistiske paradis en slange? Jo. For mig at se er alle de angivne resultater fejlagtige. For at se dette må vi tage udgangspunkt i energiforslagets beregningsoversigt.

\begin{tabular}{lccccc}
\hline & $\begin{array}{c}\text { brutto } \\
\text { invest. } \\
\text { mia. }\end{array}$ & $\begin{array}{c}\text { antal } \\
\text { helårs } \\
\text { jobs }\end{array}$ & $\begin{array}{c}\text { netto } \\
\text { invest. } \\
\text { mia. }\end{array}$ & $\begin{array}{c}\text { mio. } \\
\text { Gcal } \\
1981\end{array}$ & $\begin{array}{c}\text { årlig valuta- } \\
\text { besparelse } \\
1981\end{array}$ \\
\hline vindkraft & 4,0 & 30.000 & 1,8 & 7 & 270 mio \\
kraftvarme & 2,4 & 17.000 & 1,1 & 5 & 200 mio \\
naturgas & 5,8 & 29.000 & 3,6 & 20 & 1200 mio \\
isolering & 10,5 & 89.500 & 3,8 & 29 & 1160 mio \\
solenergi & 3,0 & 22.000 & 1,4 & 4 & 160 mio \\
\hline I alt & 25,7 & 187.500 & 11,7 & 65 & 2990 mio \\
\hline pr. år & 6,4 & 47.000 & 2,9 & 65 & 2990 mio
\end{tabular}

Beregningen af forslagenes beskæftigelseseffekt foregår på den måde, at man simpelt hen udregner, hvor mange helårsbeskæftigede den pågældende aktivitet teknisk set ville give anledning til. Ifølge skemaet svarer beskæftigelseseffekten altså til det antal arbejdere, der skal bruges til at producere/spare 65 mio. Gcal pr. år på de måder, som forslaget fremfører.

Men denne beregning er statisk, dvs. ahistorisk. Som den er opstillet, kan den fortolkes på to måder. Enten forudsætter beregningen, at der i Danmark oven $i$ den i dag igangværende energiforsyning skal produceres/spares 65 mio. Gcal pr. år. Men i så fald vil den årlige valutabesparelse på 2990 mio. kr. falde bort, thi det pågældende forbrug af energi, som er produceret af multinational kapital opretholdes. I så fald er planens фkonomiske konsekvensberegninger fejlagtige.

I $\varnothing$ vrigt burde planen så beregne effekterne af det stærkt forøgede energiforbrug, som vel hverken var særlig »nationaløkonomisk « fordelagtigt (for nu at tale i planens og den borgerlige $\emptyset$ konomis terminologi) eller særlig flatterende ud fra en $\varnothing$ kologisk synsvinkel. Denne for $\varnothing$ gelse af energiforbruget ville i $\varnothing$ vrigt være mere markant, end det umiddelbart fremgår af tallene. Planen tilslører nemlig sine forbrugseffekter p.gr.af den besynderlige sammenblanding af energibesparelse og energiproduktion. Isoleringsafsnittets 29 mio Gcal pr. år er en besparelse. Dvs. at planen forudsætter en forøgelse af energiforbruget på 65 mio. Gcal, en forøgelse som ligger uden for forbruget til opvarmning (hvor man jo isolerer). 
Der er altså tale om »beregningsfusk «. Hvorfor? Fordi - efter min mening - planen skal repræsentere en arbejderinteresse v.hj.af en borgerlig $\emptyset$ konomi. Dette lader sig tilsyneladende ikke gøre, hvilket blot er et indirekte udtryk for, at løsningen af den kapitalistiske krise (og af de kriseformer, den fremtræder i) sker på bekostning af arbejderklassens interesser, dvs. at arbejderinteresserne ikke kan tilgodeses inden for rammerne af en kriseramt kapitalisme.

\section{BBP og klassekampen}

Når grundlaget for ens overvejelser er »teknisk realisme«, så bliver konsekvensberegningerne også tekniske: De »klassekampsmæssige konsekvensberegninger « udelades.

Ulemperne herved er særlig tydelige i energiforslaget (og i den oprindelige plans fyringsafgift). Forudsætningen for forslaget er at der investeres 25,7 mia. $\mathrm{kr}$. i aktiviteter, som udgør danske alternativer til udenlandsk energiforsyning. Man forestiller sig altså, at der via et statsligt påbud vil ske en radikal forringelse af de multinationale olieselskabers afsætningsmuligheder på det danske marked.

Spørgsmålet er, om disse olieselskaber accepterer dette og bare forlader landet med hatten i hånden (til ærbødigt farvel og med henblik på indøvelse af en kommende VS- og statsdikteret tiggergestus)?

Det sandsynlige svar er, at det gør de ikke. Men derudover må det fremhæves - og det er det vigtigste - at de multinationale olieselskaber ikke blot er direktioner, de er også kapital. Og der er her tale om kapital, som er investeret i mange andre aktiviteter end de direkte berørte. Den nærliggende konsekvens er, at der vil ske en kolossal kapitaloverførsel ud af landet.

\footnotetext{
Den anden fortolkningsmulighed er, at BBPs energiforslag ikke forudsætter en absolut forøgelse af det danske energiforbrug svarende til planens omfang. I så fald betyder det, at der ved siden af det foreslåede energiprogram sker en reduktion i den nuværende energiforsyning på (højst - man kan jo tænke sig alle mulige mellemformer mellem de to anførte fortolkningsmuligheder) 65 mio. Gcal pr. år. I så fald holder tallene for den årlige valutabesparelse, hvorimod beskæftigelsestallene er fejlagtige. Her glemmer man nemlig at trække det antal (inden- og udenlandske) arbejdere fra, som bliver afskediget p.gr.af tvangsomlægningen af energiproduktionen.

Planen har sandsynligvis ikke lagt sig fast på én af de to fortolkningsmuligheder. Tværtimod bruger den dem i flæng, afhængigt af hvilken mulighed der giver det mest fordelagtige resultat: Den første når beskæftigelseseffekten skal beregnes, den sidste når valutabesparelsen skal beregnes. Herigennem bliver forslaget for mig at se dæmagogisk - en effekt som ganske givet ikke er tilsigtet, men som skyldes, at man modstandsløst bruger - og misbruger - en borgerlig $\emptyset$ konomis ahistoriske effektberegningsmetoder.
} 
Men den vil VS måske forbyde, f.eks. ved ekspropriering af de udenlandske selskabers ejendom i Danmark? I så fald vil den sandsynlige reaktion være politiske repressalier i et omfang, som er vanskeligt at forene med en anden forudsætning i energiplanen, nemlig at der skal ske investeringer i dansk energi på 25,7 mia. kr., velsagtens delvis finansieret via velvillige lån fra udlandet!

Værst er imidlertid nok, at BBP ved dette skizofrene forhold til klassekampen rummer en betydelig grad af passiviserende illusionsmageri. Indirekte siger den - i forslag som det just behandlede - at kapitalismen kan ændres i et betydeligt omfang uden at der står arbejdermagt bag ændringerne. Igen præsenteres vi for et problem, som vi bedst kender fra den socialdemokratiske parlamentariske praksis.

\section{$B B P$ - utilsigtet statsbyrokratisme}

Hvordan er BBP konstrueret? Ikke på grundlag af en historisk analyse af udviklingsperspektiverne i det aktuelle kapitalistiske samfund. En sådan analyse kunne på et alment plan bygge på tendenserne i den kapitalistiske kriseudvikling frem mod et samfundsmæssigt sammenbrud med en heri indeholdt kvalitativ ændring i klassekampene. Eller den kunne på et konkretere niveau unders $\varnothing$ ge de klassemæssige styrkeforhold, de nationale kapitalers konkurrencesituation på verdensmarkedet, statslige indgrebstendenser osv. osv.

BBP er konstrueret på en helt anden måde. Den er en matematisk model, som fungerer på følgende måde: Hvis »man « gennemfører en plan for boligbyggeri, A, så har det en beskæftigelseseffekt på 20.000 pr. år. Hvis »man « gennemfører en energiplan, B, så har det en beskæftigelseseffekt på 44.000 pr. år. Osv.

Derefter udregner BBP konsekvenserne for de offentlige budgetter og for betalingsbalancen v.hj.af følgende forudsætninger: De offentlige budgetter beregnes v.hj.af besparelsen pr. nybeskæftiget person i den private sektor (75.000 kr. i sparet arbejdsløshedsunderstøttelse m.v.) minus udgiften pr. nybeskæftiget person i den offentlige sektor $(15.000 \mathrm{kr}$. mere end udgifterne til undersøttelse). Hertil lægges de direkte offentlige besparelser/ udgifter i forbindelse med de konkrete projekter. Betalingsbalancen beregnes v.hj.af importforøgelsen pr. beskæftiget plus importbehov m.v. i forbindelse med de konkrete projekter.

Hertil knytter der sig nogle problemer.

For det første bygger BBP på en række forudsætninger, som sikkert er i overensstemmelse med den bedste borgerlige $\varnothing$ konomiks og politologis 
forskrifter (forskrifter om at det statslige påbud har den effekt, det subsidie den effekt, og forskrifter om hvilke talstørrelser man kan regne med i de $\varnothing$ konomiske konsekvensberegninger). Problemet er dels at disse forudsætninger er abstrakte. Man fristes til at henvise til Erik Møller og Knud Erik Skoubys kritik af den danske perspektivplanlægning, om hvilken de siger, at den opererer med et abstrakt planlagnningsbegreb, der "principielt gælder både den private planlægning af en tur i byen og den overordnede samfundsplanlægning « ${ }^{43}$ Men dels er problemet, at planlægningsbegrebet dog ikke er mere abstrakt end at det er relateret til planer, der lægges og udføres af et suverænt subjekt, det være sig det individ, der er suverænt mht. planlægningen af aftenturen og det statslige subjekt, som i borgerlige politologers fantasi er suverænt mht. planlægningen af samfundets udvikling. Disse forudsætninger har således intet at gøre med »samfundsudvikling « i marxistisk forstand.

For det andet opererer planen imidlertid med yderligere én forudsætning: Det »man«, der sætter alle planens aktiviteter i gang. Hvem afg $\phi r$ dette »man«s styrke? Det gør alene planens forfattere bag skrivebordet. Planen er måske langt hen «teknisk realistisk «. Men den ville være lige så »teknisk realistisk«, hvis den blev forsynet med helt andre inputs. I dette stykke forekommer planen lige så dæmagogisk som f.eks. et forslag om at «inddrage »værdi« stigningerne på jord og fast ejendom og bruge beløbet til at afskaffe arbejdsløsheden med «. Forskellen er principielt set kun, at VS-forslaget er langt mere »teknisk « indviklet og derfor langt mindre gennemskueligt.

Det tredje problem er: Hvem er dette »man«? Ifølge planen skulle det være »arbejderklassen «. Planen skulle jo nemlig bidrage til «at arbejderklassen overvinder selvopgivelsen « og »formulerer sine egne krav« (dvs. BBP). BBP tager angiveligt «sigte på at formulere de krav, som arbejderklassen må tvinge igennem «. Men når arbejderne strejker på Lind, , når de besætter en virksomhed, så sker det hverken som led i en samlet plan for beskæftigelse og betalingsbalance eller på grundlag af «teknisk realistiske« konsekvensberegninger - i øvrigt synker også al salgs »teknisk realisme « $\mathrm{i}$ grus ved den slags lejligheder. Den eneste slags »arbejdermagt «, som kan tænkes at gennemtvinge planer om BBP, er den slags arbejdermagt, som forsamles foran Christiansborg!

En model som BBP rummer én bestemt forudsætning: eksistensen af en suveræn, politisk styrbar overdeterminator: Staten. Dette kom indirekte til udtryk, da VS efter den første lancering af BBP fjernede forslaget om

43. Erik Møller og Knud Erik Skouby: »Om grænser for den statslige aktivitet«. In: Socialistiske $\emptyset$ konomers Krise i Danmark, Roskilde 1977, s. 205. 
fyringsafgift (en afgift som kapitalisten skulle betale ved fyringer og som skulle tvinge ham til at fortsætte den hidtidige produktion på et lavere profitniveau). Hvad gjorde man? Man pillede elementet ud af planen og trak samtidig fyringsafgift-elementets konsekvenser for beskæftigelse og betalingsbalance fra de totale tal.

Denne fiktive verden, hvor det teknisk- $\varnothing$ konomiske afgøres i studerekammeret (med passer og lineal, med logaritmetabel og sandsynlighedskurver) hvor findes den? Den findes i stats-byrokratens visioner om den fuldkomne verden, den verden som fuldstændig er underlagt statsmagtens kontrol: Hvor man trykker på en knap, vedtager en lov, foretager et indgreb, hvorefter virkeligheden retter sig efter indgrebet. I sådanne formuleringer er planen billedet af det fuldbyrdede statsbyrokrati! I sit indhold (og ikke i sin hensigt, selvfølgelig) er BBP billedet af de akademiske fag $\varnothing$ konomers og partifunktionærers virke i de statslige planbyroer, hvorved den unægtelig står i modsætning til visionen om den selvorganiserede, arbejderkommunistiske ledelse og fordeling af produktion og forbrug.

\section{BBP og det borgerlige parlament}

Når man nu ved, at der bag BBP står personer, som på ingen måde kan beskyldes for at nære ønske om en udvikling som den, BBP indebærer, så bliver planen et desto klarere dokument på, hvad der sker, når nok så gode socialistiske viljer integreres i det borgerlige samfund. Det forekommer mig, at BBP på alle måder afspejler den prægningseffekt, som de borgerlige institutioner har på deres (nok så subversive) aktører.

Preben Wilhjelm skriver bag på sin pjece om »Det repræsentative demokrati i praksis «: »Går man ind i dette system med sin kritiske sans i behold, kan man ikke undgå at se, at man derved bliver statist i deres skuespil, og således er med til at redde hele forestillingen, altså at legitimere det, der foregår. Det $\emptyset$ nsker vi ikke. Vi er der af helt andre grunde, og vi må bevidst modvirke den opfattelse, at vi fungerer som en slangs garanter for, at alt går rigtigt til.«

Som jeg har fors $\emptyset \mathrm{gt}$ at vise, mener jeg ikke, at man under de givne omstændigheder kan gå ind i systemet og - v.hj.af intelligens og kritisk sans - afsløre det indefra eller indefra tvinge det til selvafsløring.

Tværtimod mener jeg, at man på trods af disse og sikkert mange andre gode egenskaber og intentioner ikke kun bliver «statist i deres skuespil«, men risikerer at blive aktør i overensstemmelse med deres spilleregler. 


\section{BBP som parti-masse-didaktik}

Den angivelige hensigt med BBP var - som allerede nævnt - at delegitimere SD for øjnene af arbejderklassen: »Ideen med planen er at give folk på arbejdspladserne, institutionerne og mange andre steder en anden synsvinkel på Socialdemokratiets og de borgerliges krisepolitik. «44

Som jeg har prøvet at vise mislykkedes dette forehavende: For det første var planen ikke realistisk. For det andet opviste den ophobning af forvirrende selvmodsigelser:

På den ene side fremsattes den som en plan i Folketinget - på den anden side anførte den selv, at folketinget er »administrator (...) af de kapitalistiske samfund. $\ll 45$

På den ene side formulerede planen de krav, som »arbejderklassen må tvinge igennem $\aleph^{46}$ på den anden side var planen »teknisk realistisk «, og denne »tekniske realisme« var »renset« for klassekamp.

På den ene side skulle forslaget give arbejderklassen en ny synsvinkel på den socialdemokratiske kriselovgivning, uden at give anledning til »forræderiopfattelser « - på den anden side tog forslaget gentagne gange socialdemokratiske forslag op; den anskueliggjorde altså at SD er »godt nok «, men at det har svigtet sine egne principper. Angiveligt fordi SD er forræderisk: Det »har aldrig haft bekæmpelse af arbejdsløshed som sit fornemste mål, men har derimod sigtet $\bmod (\ldots)$ at $\varnothing$ ge profitterne, (...) at styrke kapitalismen og gøre den mere levedygtig på lønarbejdernes bekostning. $\ll^{47}$

På den ene side er hensigten med forslaget at helbrede det kapitalistiske samfund (løse arbejdsløshedsproblemet uden at »ramme« betalingsbalancen) - på den anden side er hensigten at uddybe den kapitalistiske krise.

Hvad er baggrunden? At planen på den ene side ønskede at indtage et arbejderstandpunkt - på den anden side var formuleret ud fra et statsstandpunkt.

For det tredje var planen - som allerede nævnt - ikke et socialistisk alternativ til SD, men et »venstresocialdemokratisk « alternativ til en »højresocialdemokratisk« politik.

Hvorfor? Fordi planen formulerede et »alternativ« til »modstanderne « på modstandernes præmisser, nemlig på præmisser, som var leveret af det borgerlige parlament og kapitalismens »tekniske« realisme.

44. BBP op.cit. s. 1.

45. Ibid. s. 3 .

46. Ibid. s. 2.

47. Ibid. s. 3. 
Hvorfor repræsenterede planen ikke det arbejderstandpunkt, som den gerne ville? Jeg mener at det hænger sammen med, at planen er et parti-produkt: Partiets intention er at stille sig i spidsen for arbejderklassen, »formulere dens $k r a v \ll, ~ » g i v e$ den en synsvinkel« osv. Herved bliver planen som agitation ikke et talerør for arbejderstandpunktet, men en - relativt autonom - gruppe akademikeres og parlamentarikeres anvisning til arbejderklassen.

Det er et udtryk for denne misere at man i planen kan konstatere en adskillelse mellem de antikapitalistiske strømninger, der findes i Danmark (strejkebevægelser, boligbevægelser etc.) og formuleringerne i BBP som statsplan. Det er derfor, at denne adskillelse som eksemplificeret bliver til formynderi.

Når denne adskillelse bliver for stor, så toner arbejderstandpunktets fornuft bort til fordel for en mere nærliggende fornuft: Statsfornuften. Herved bliver BBP en brik til forklaringen på, at der altid tillægges venstrefløjen visioner om at staten skulle være midlet til at komme videre mod socialismen.

Dette spidsformulerer så igen den socialhistoriske opfattelses magtsociologiske billede af kapitalismen: Den kapitalistiske kriseudvikling vil - ifølge denne opfattelse - kunne ændres ved at én faktor udskiftes, nemlig hvis SD erstattes med f.eks. VS. Heroverfor kan BBP fremholdes som det embryonale eksempel på magtsociologiens fejlagtighed: Hvis SD - under betingelser der i $\varnothing v$ rigt er uændrede - udskiftes med VS ${ }^{48}$ er det ikke udviklingen, men VS der ændres.

\section{KF - opportunistisk entusiasme}

\section{a. Besværgelse af historien}

Som nævnt i indledningen til afsnittet om VS beskrev Brückner og Krovoza i 1972, hvorledes partiet blev lanceret som patentmedicin på den utilfredsstillende historiske udvikling.

Som bekendt er der to vigtige karakteristika ved den slags medicin: For det første kurerer den ikke sygdommen, men fjerne evt. symptomerne: Den kurerede ikke den historiske skæv-vækst, men nok til en vis grad de skuffelser, som

48. Eller et hvilket som helst socialistisk parti af gammel eller ny type. 
historien havde beredt venstrefløjen. For det andet skal patienten have blind tillid til pillernes magiske virkninger.

KF er en organisation, som ifølge denne metaforik må karakteriseres som en meget tillidsfuld pillemisbruger. De seneste år har partiet gjort sig bemærket ved stadig mere fantasifulde forsøg på at besværge historien v.hj.af partiet jvf. den leninistiske fløjs afskalning fra VS og dannelsen af KF, jvf. de senere strategi-fors $\varnothing \mathrm{g}-$ og v.hj.af detaljerede strategier anvisende »vejen til socialismen«. I de sidste par år har forholdet mellem strategi og parti nærmest være følgende: Problemet er at få historien til at indrette sig efter den strategi/den vej til socialismen, som KF anviser; løsningen er partiet: v.hj.af partiet sættes historien på sporet af KFs strategi.

\section{b. »Vejen til socialisme ...«}

Revolutionen skal ikke virkeliggøre abstrakte idealer, men frigøre allerede eksisterende tendenser. Således kunne man omskrive Karl Marx og Ernst Bloch. ${ }^{49}$

Fejlen i KF's »vej til socialisme « - således som den er udlagt af Bent $\mathrm{Moos}^{50}$ - er, at den ikke overholder denne materialistiske grundsætning. Her vendes sagerne konsekvent på hovedet, således at grundlaget for den revolutionære praksis bliver de abstrakte idealer, og de overskridende »eksisterende tendenser « bliver produkter af idealet.

BMs store fortjeneste er at danne en slags antitese til VSs stivnede fantasiløshed. Udgangspunktet for BM kunne være én af konklusionerne på BBPkritikken: »En af den revolutionære venstrefløjs hovedsvagheder i dag er den manglende evne til at opstille et klart og forståeligt alternativ til den kriseramte kapitalisme«, et alternativ »der viser den fundamentale forskel til Socialdemokratiets velfærdssamfund eller DKP's statssamfund ... $\ll^{51}$

BMs afgørende svaghed er, at han kun danner antitese til fantasiløsheden, dvs. at han er fantasiløshedens abstrakt fantasifulde modsætning. »Som alle hurtigt vil opdage, rummer dette debatoplæg ikke et fors $\emptyset \mathrm{g}$ på en analyse af den aktuelle klassekamps- og krisesituation eller udviklingen af en konkret politik på bestemte områder. Debatoplæggets formål er derimod (!) at bidrage til en mere fundamental politisk afklaring af målsætning og strategi

49. Jvf. Ernst Bloch: Prinzip Hoffnung. Frankfurt a.M. 1977.

50. Bent Moos: »Vejen til socialisme i Danmark« In: Vejen til socialisme nr. 3 juni 1977 s. 5-37. Debatoplægget er efter sigende senere med ændringer blevet kanoniseret af (resterne af) KF.

51. Ibid. s. 7. 
for revolutionen i højtudviklede kapitalistiske lande med solide borgerligdemokratiske traditioner. $\ll^{52} \mathrm{BM}$ forstår m.a.o. ikke enheden mellem analysen af »klassekamps- og krisesituationen« og de strategiske overvejelser. Tværtimod bliver utopien til handlingsanviser og -igangsætter: »Får vi først klargjort de strategiske hovedlinjer, vi skal handle og tænke praktisk ud fra, vil det give muligheder for at løse en lang række aktuelle politiske problemer. $\ll^{53}$

Denne dårlige entusiasme præger hele BMs debatoplæg. Det er ganske enkelt disponeret som en lang tilbageslutning fra det abstrakte fjernmål, kommunismen. Tværtimod at utopien er en overskridende mulighed i de foreliggende samfundsmæssige modsætninger er det for BM sådan, at nutiden har at indrette sig efter fjernmålet. BMs argumentation ligner de natdrømme, hvis »realisme « beror på en nøjagtighed i detaljen, som gør dem troværdige lige indtil den ubehagelige opvågnen.

BM bygger sit korthus fra toppen: »Efter magtovertagelsen $~^{54}$ skal følgende punkter opfyldes: ${ }^{55}$

1. Organisering af hele befolkningen på grundlag af samfundsnødvendigt arbejde.

2. Opbygning af en ny type magt: Arbejdernes magt over arbejdspladserne. Byråds-demokrati erstattes med rådsdemokrati. Selvforsvarsbevæbning.

3. Socialisering af produktion og distribution.

4. Ophævelse af den borgerlige familieinstitution.

5. Kamp mod arbejdsdeling af alle typer.

Men - dette forudsætter ..., siger BM som første led i sin tilbageslutningsprocedure: »Skal revolutionsprogrammet i det foregående afsnit være andet end en smuk utopi, må det være uløseligt forbundet med en konkret og realistisk revolutionsopfattelse, der kan vise en klar vej til dets gennemførelse. ${ }^{56}$ Hvis »revolutionsprogrammet « skal sættes igang, skal det først sættes på skinner. Hertil kræves en socialistisk revolution. Igen går BM til værks med en omhyggelig detaljerethed: »En revolutionær situation kraver en ophobning og forening af kriser på mange forskellige områder der rammer alle klasser, dvs. en samlet national krise, der ryster alle klasser. Det krcever en situation, hvor borgerskabets styrke ikke er intakt (splittelse mellem fraktioner om hvad der skal gøres -

52. Bent Moos er selv klar over problemet (omend han ikke tager højde for det): »Det er selvfølgelig ikke nok at opstille kommunismens principper som alternativ. (...) Det vil blot fremtræde som utopi, dvs. en fjern, mystisk fremtid, uden reel forpligtelse for arbejderklassens strategi og taktik i dag.« (Ibid. s. 7).

53. Ibid. s. 6.

54. Ibid. s. 11.

55. Ibid. s. 11-19.

56. Ibid. s. 19. 
splittelse i og desorganisering af statsapparatet). Det kraever at brede dele af arbejderklassen er inddraget i kamp som udtryk for at de ikke længere er parate til at leve som før. Endelig kraver det at væsentlige dele af de sociale klasser mellem borgerskab og arbejderklasse er i opbrud, væk fra den hidtidige underordning i alliancer med borgerskabet. $«{ }^{57}$ Her bliver den $»$ detaljerede galskab « helt tydelig. Dels fremgår den revolutionære situation ikke af samfundsmæssige modsætninger; i BMs idealistiske visioner er de samfundsmæssige modsætninger og »styrkeforhold « tydeligvis et resultat af efterrationalisering - de er »nødvendige forudsætninger for « revolutionen.$^{58}$ Og dels bliver analysen en analyse af magtspil, hvis grundlag er svævende - er udtryk for at man »ikke er parat til at leve som $f \varnothing r \ll !$

Stadigvæk synes afstanden til »dagens Danmark« med SV-regering og almindelig resignation at være stor. Men ikke for BM: »I de højtudviklede imperialistiske lande med stærke borgerlige-demokratiske traditioner står vi over for en umiddelbar socialistisk revolution. ${ }^{58 a} \mathrm{Vi}$ skal blot lige have indledt denne revolution! »Gennemførelsen af et virkeligt rådsdemokrati (...) afhænger (...) af, om de afgørende strategiske betingelser er skabt i den forudgående revolutionære proces. Den strategiske hovedopgave der derfor står tilbage er at finde særlige former for indledningsstrategier, der kan bidrage til at den revolutionære proces skaber disse betingelser. $\ll{ }^{59}$ Det tryllemiddel, som ifølge BM kan sætte den revolutionære snebold i gang, er: »en arbejderregering af en ny type. « ${ }^{60}$ Og igen blomstrer fantasien: venstrefløjen skal gennemføre »en indledende reformfase « som åbner for »en troværdig politisk offensiv på nationalt plan«. Der skal etableres »direkte samarbejde mellem masseorganisationerne og de progressive dele af statsapparatet«, bl.a. »forberedt lokalt af venstreorienterede kommunalbestyrelser «! ${ }^{16}$

Alt i alt opstiller BM en fiktiv verden for handlingsivrige revolutionære, hvor alle problemer er reduceret til problemet om at komme i gang: »den virkelige ændring af styrkeforholdene til fordel for de revolutionære tendenser (sker) først afgørende når der åbnes for nye styrkeforhold « udråber BM med en karakteristisk blanding af tautologi, magtfixering og venstrefløjen som slusemester for de påtrængende revolutionære masser. ${ }^{62}$

57. Ibid. s. 21.

58. Den ordnende determinator i citatet er »den revolutionære situation». Summen af samfundsmæssige modsætninger bestemmes af, hvilke krav til samfundsrelationerne denne situation stiller!

58a. Ibid. s. 20.

59. Ibid. s. 24.

60. Ibid. s. 24.

61. Ibid. s. $24 \mathrm{f}$.

62. Ibid. s. 26. 


\section{c. Partiets selvfølgelige nødvendighed}

Hvordan skal man da komme i gang? Ved hjælp af partiet, selvfølgelig! Inderst inde - hævdes det fortrøstningsfuldt - er arbejdere m.fl. kommunister: »Det er kun kommunismen, der betyder realiseringen af alle radikale behov for et nyt liv, der i dag eksisterer hos de udbyttede og undertrykte ... ${ }^{63}$ Disse $»$ radikale behov « har man dog i virkeligheden ikke nogen tillid til; med noget besvær forsøger man at udtrykke en avantgardelinje v.hj.af ord, der skal associere til en spontant-demokratisk masselinje: Man skal »opbygge ${ }^{64}$ en $»$ folkelig selvorganisering «, »og det kan kun ske ved at kampene og bevægelserne udvikles organisatorisk. $\ll^{65} 66$

Igen præsenteres vi - når hykleriet brister - for den opfattelse, at den historiske dynamik indføres udefra, fra Socialdemokratiet eller fra et venstre-parti (og for en uanfægtelig tro på sin egen fortræffelighed: Det såkaldt »revolutionære venstre«s prægning er et indiskutabelt gode): »Det er indlysende, at hvis det revolutionære venstre virkelig skal formå at præge alle de forskellige forsvarskampe og bevægelser i samme, offensive retning, kræver det, at indsatsen er politisk og organisatorisk koordineret gennem et parti. « ${ }^{67}$ Bag lovprisningerne af folkedemokratiet ligger en tro på masserne, som kan sammenlignes med generalens tillid til de menige.

\section{d. Indsmigring i arbejderklassen}

Tilsyneladende består forskellen mellem VS og KF med hensyn til reformismeproblemet i, hvordan man skal rykke Socialdemokratiet og arbejderklassen fra hinanden: Hos VS ved at delegitimere SD. Hos KF ved at indynde sig i arbejderklassen: $\mathrm{KF} »$ afviser (...) hele grundlaget for afsløringspolitikken over-

63. Ibid. s. 8.

64. Hvem skal »opbygge« denne såkaldte selvorganisering? Det skal »reformkampen« (VtS nr. 11, s. 21). Hvor stammer »reformkampen« fra? Fra »de reformkrav, som vi fremsætter og forsøger at mobilisere bevægelserne omkring « (Ibid. s. 19). Hvem er »vi«? Det er »det revolutionære venstre« (Ibid s. 19). For det er nemlig »venstrefløjen« der »på alle områder skal udvikle forsvarskampen til en offensiv for reformer, der peger frem mod en socialistisk revolution« (Ibid. s. 19).

65. Klas Birkholm: »En revolutionær reformstrategi.« In: Vejen til socialisme nr. 11. Fjerritslev nov/dec 1978. s. 22.

66. Eller - som det formynderisk bekymret hedder i en billedtekst under et fotografi af »demonstrerende arbejderungdom«: »De kender hulheden bag fraserne om »velfærdssamfundet «. Men hvor skal deres protest ende, hvis det revolutionære venstre ikke udvikler et alternativ til Socialdemokratiets krisepolitik?« (Ibid. s. 29).

67. Ibid. s. 26. Samme selvklare påstand findes i øvrigt identisk i VtS 11. 
for $\mathrm{SD} \ll$. I stedet må udviklingen af »modsætninger i SD og mellem SD og fagbevægelse (...) underst $\varnothing t t e s$ af et konsekvent arbejde fra venstrefløjen for at udbygge det til en virkelig aktionsenhed med SD-arbejdere. Det forudsætter, at venstrefløjen ikke som forudsætning opstiller grundlag, der forudsætter brud med SD. $\ll^{68}$

Hermed bliver det et afgørende og overskyggende problem for KF at overskride troværdighedskløften til arbejderklassen. Således skriver man (med en brug af ord som »samfunds- $\varnothing$ konomien«, »løsninger «, »ansvarlighed « og »troværdighed « og med en ubehageligt-velkendt omgang med begrebet »anarkisme « som etikette for u-borgerlig uorden, der med forstemmende tydelighed udtrykker tendenser på den kriseramte venstrefløj): »Det revolutionære venstre's politik over for krisen må ikke tage udgangspunkt i paroler som »vis ingen hensyn til samfundsøkonomien«, »stil krav der uddyber kapitalismens krise« o.lign. Det er i realiteten anarkistiske paroler! Tværtimod må vi allerede i dag gøre det klart, at det revolutionære venstre har ansvarlige løsninger på den situation, der vil opstå efter en socialistisk omvæltning i Danmark, hvor betalingsbalance-problemet fortsat er en realitet. Viser vi ikke ansvarlighed overfor denne type problemer, forekommer vores politik utroværdig for arbejderklassens store flertal - og med rette! $\ll^{69}$ Det »revolutionære venstre « skal simpelthen fremstå mere »ansvarligt « end - Socialdemokratiet. Venstrefløjen skal optræde »mere positivt «: der skal opstilles »alternative reformforslag «, i hvilke »der ikke kun siges »nej«, men også peges på nye veje og alternativer.$^{70}$

\section{e. Eksemplifikation af de »ansvarlige« talemåders omkostninger}

Man kan ikke både blæse og have mel i munden. ${ }^{71}$ Tilsvarende kan KF (og mange andre) ikke optræde som »ansvarlig « i borgerlig forstand og samtidig bevare et revolutionært grundlag. Når »det ansvarlige « - den øjeblikkelige succes på trods af alle udsagn om de øjeblikkelige muligheders begrænsning - vejer tungere end »det revolutionære«, så må sidstnævnte vige.

For det første harmonerer de »ansvarlige løsninger« ikke med en marxistisk kriseteori. Ergo dropper man marxismen til fordel for et misk-mask

68. KF/RSF: Diskussionsbulletin. September 1978. upagineret.

69. Klavs Birkholm: »En revolutionær beskæftigelses- og betalingsbalanceplan?« In: Vejen til socialisme nr. 8. Fjerritslev april 1978 s. 15.

70. Bent Moos op.cit. s. 32.

71. Udgår. 
af den borgerlige $\varnothing$ konomis bortforklaringer: Krisen er ikke kapitalistisk, den er alt mulig andet: »Krisens årsager må søges $i$ et sammenhangende kompleks af fanomener, der tilsammen karakteriserer det danske efterkrigssamfunds politisk- $\varnothing$ konomiske struktur. Her kan blot (?) nævnes underkastelsen under den amerikanske dollarimperialisme på den vestlige verdens markeder, accepten af enorme spekulative kapitalindkomster (på jord, fast ejendom, pantebreve, kommanditselskaber osv.), et stadig mere opskruet renteniveau, monopolselskabernes tiltagende markedskontrol etc. ${ }^{72}$ Allerede $\varnothing$ nsket om at finde »årsager« blandt »fænomenerne « viser, at KF er på vildspor.

For det andet bliver det vanskeligt at afgrænse sig til Socialdemokratiet. På den ene side må man selv optræde som SD for at virke troværdig. På den anden side er SD jo ikke-revolutionært. Forskellen beror altså på viljen: Den er skidt hos SD, god hos KF.

Igen markerer KF dilemmaet med en beundringsværdig tydelighed: I en gennemgang af BBP roses planen ét sted for at indeholde en række "parlamentariske alternativer, som umiddelbart kunne gennemføres, hvis SD afbrød samarbejdet med de borgerlige og i stedet indgik forlig med partierne tilvenstre i Folketinget.« Et andet sted skriver man: »Mange mennesker vil helt selvfølgeligt opleve BBP som et krav om, at SD opgiver samarbejdet med de borgerlige og i stedet giver sig til at samarbejde med venstrepartierne i Folketinget. (...) Det er faktisk temmelig uheldigt! Det revolutionære venstre må vende sig mod alle illusioner om, at et arbejderflertal vil kunne udgøre et reelt alternativ i øjeblikket. «73

Men hvorfor vil SD da ikke være med til at løse krisen (oven i købet med en række respektable partier)? KFs eneste »forklaring « er forræderiforklaringen: »En sådan SD-regering vil efter alt at dømme fortsætte med en arbejderfjendsk politik, og samtidig vil den gøre alt for at inddrage SF og DKP i bestræbelserne for at dæmme op for arbejderbevægelsens modstandskamp.« - Og for at gøre uklarheden fuldstændig fortsættes der: »Det revolutionære venstre må advare imod dette, samtidig med at et nyt arbejderflertal naturligvis må hilses velkomment som en udvikling i den rigtige retning. $\ll^{74}$

72. VTS 8 s. 15. Et tilsvarende greb i godteposen af »fænomener/årsager« finder man i vejen til socialisme nr. 1 s. 21-40. Her byder Birger Linde på fem »kriseårsager«, hvoraf de fleste ikke svarer til Klavs Birkholms!

73. Klavs Birkholm: »En revolutionær beskæftigelses- og betalingsbalanceplan?« op.cit. s. 13 og s. 17.

74. Ibid. s. $17 f$. 


\section{f. KF står ikke alene}

Den teoretiske og strategiske tendens, som jeg har skildret ovenfor, står KF ikke alene med. F.eks. har Mihail Larsen og Søren Keldorff hævdet af den er udbredt på universiteterne: »Fagkritikken er mange steder blevet en ukritisk opbakning af de stærke arbejderorganisationer. Studenterne støtter arbejderklassen pr. automatik. (...) De studerende laver det, som de tror arbejderne vil have. De er ved at gøre sig selv til funktionærer for arbejderklassen i misforstået solidaritet. $\ll^{75}$

Og tilsvarende står KF ikke alene med forvanskningen af kriseteorien. Tværtimod vrimler det i фjeblikket med »strukturkriseteorier «, »profitklemmeteorier« osv. osv., som alle har det til fælles, at de forklarer den kapitalistiske krise ud fra den kapitalistiske krise, årsagen ved hjælp af fænomenerne, dvs. fænomenet ved hjælp af fænomenet selv. ${ }^{76}$

Hvorfor? Jeg har ovenfor forsøgt at antyde forbindelserne mellem krisen siden 1973, den revolutionære masseudviklings tilsyneladende træghed og det nye venstres selvforståede isolation. Lad mig - for at undgå misforståelser - understrege at jeg ikke forklarer den teoretiske og strategiske »degenerering « med den leninistiske strategi og organisationsform, men blot har påvist en sammenhæng - en »positiv korrelation « - mellem disse to fænomener.

På tilsvarende måde indgår der en lang række andre faktorer i venstrefløjens udvikling. Således har den universitære socialisation sikkert en vigtig del af skylden. I det omfang den universitære videnskab ikke (som det snarere var tilfældet i studenterbevægelsens ungdom) er skrevet på baggrund af en praktisk opposition til det borgerlige uddannelsessystem vil den gennemsnitligt $t^{77}$ blive »systemets videnskab $\ll$. Og jeg mener at der er en klar tendens til integration af den oppositionelle studenterbevægelse. Den integreres, f.eks. ved at skulle kvalificere sig til at skrive lærebøger, der kan anvendes andre steder i uddannelsessystemet. ${ }^{78}$ Den integreres ved at skulle gøre sig nyttig for staten for at kunne opretholde sin legitimation. Den integreres ved at undervisningen (og kravene til undervisningen) i takt med væksten i arbe-

75. Politiken d. 12/11 1978.

76. Socialistiske $\varnothing$ konomer er nok de tydeligste repræsentanter for denne tendens, jvf. Lars Qvortrup: Den kapitalistiske krise - Den kapitalistiske krise og de proklameret socialistiske kriseteoriers krise. Odense 1979.

77. Jeg ønsker altså ikke at bortdeterminere undtagelsen. Jeg behandler udelukkende udviklingen som tendens.

78. To gode eksempler er: Dencik og Kongshøj Madsen: Krise og krisepolitik og sammes Kriseteori, begge på Samfundsmagnyt 1978. Bøgerne anbefaler sig til de samfundsfaglige grene, seminariets liniefagsundervisning og HF. 
jdsløsheden blandt akademikere bliver mere orienteret mod de kommende arbejdsgiveres krav: Studenterne i dag skal i morgen ud at slås om rektorernes, direktoraternes, amternes, kommunernes eller de private arbejdsgiveres gunst. Den integreres kort sagt efterhånden som studenterbevægelsens kamp ændres fra at være rettet $\bmod$ »systemet « til at være en kamp for at overleve $i$ systemet. $^{79}$

\section{g. Grundelementerne i den »opportunistiske entusiasme«}

Der er to hovedingredienser i den anførte strategi for $»$ vejen til socialisme «: For det første den socialhistoriske tendens's klassekampskonception. Og for det andet en opfattelse af at grundmodsatningen i kapitalismen er modsatningen mellem kapital og natur.

Som allerede nævnt findes der mange varianter på det socialhistoriske tendens's spektrum. Men i de fleste blandformer gør følgende opfattelse sig gældende: Den til enhver tid herskende reformistiske strategi er et udtryk for dominerende klassers, lags og gruppers samlede magtkonstellation. Forbindelsen mellem masse og parti er den, at masserne er udstyret med elementære interesser, mens partiet er udstyret med en samlet ideologi, strategi ell. lign. At den herskende reformistiske strategi udtrykker den samfundsmæssige magtkonstellation vil altså sige, at det er det (reformistiske) parti, der dominerer, som formår at levere en samlet strategi, som korresponderer med kombinationen af samfundsmæssige gruppers elementære interesser.

Denne opfattelse er måske tydeligst blevet reflekteret teoretisk af Niels Ole Finnemann ${ }^{80}$ Ifølge ham skal den danske reformisme forstås som »en historisk magtbalance mellem arbejderklasse, borgerskab og småborgerskab ... $\ll^{81}$

Ud fra denne grundmodel konstruerer Finnemann fire faser i den danske reformisme. 1. fases »klassiske reformisme « afløses af »den folkelig reformisme: Den folkelige reformisme i mellemkrigstiden har et system af klassealliancer omkring udøvelsen af den parlamentariske magt indenfor statsapparatet som grundlag.« Nærmere bestemt er der tale om en alliance mellem

79. Dette er en tendens, som det selvsagt er nonsens at anfægte moralsk. Men jeg vil kritisere de tydelige tendenser til at gøre en $d y d$ af denne udvikling og dens konsekvenser.

80. Jeg hævder altså en principiel overensstemmelse mellem Finnemann og KF. Detailleforskellene er tydelige, men interesserer ikke her.

81. Niels Ole Finnemann: »Reformismen ved vejs ende«. In: Socialistisk politik nr. 8, Århus dec. 1977, s. 22. Den anførte opfattelse har Finnemann overtaget fra Håkon Arvidssons artikel »Reformismens kris« i Bild-Kontrast 1977. 
arbejderklassen, »omfattende dele af småborgerskabet« og et »fredsommeligt « borgerskab. $^{82}$

Denne fase afløses igen af »den statslige reformisme« i 1960'erne: »Det direkte klassesamarbejde med borgerskabet opprioriteres, og det profilerede klassesamarbejde med småborgerskabet erstattes gradvist med de nye mellemlag, der er knyttet til institutionaliseringen og den teknologiske side af kapitalakkumulationen. $\ll^{83}$

Men i den seneste tid er der sket noget interessant med klassernes magtkonstellation, som i forhold til alle parter er uheldsvangert for Socialdemokratiet: »Reformismens forhold til borgerskabet er ved at gennemløbe en strukturel udvikling, der både stiller reformismen svagere overfor det hjemlige borgerskab og gør den mere afhængig af imperialismens ledende lande. Reformismens forhold til småborgerskabet har udviklet sig til et historisk modsætningsforhold. Reformismen i arbejderklassen udgår ikke længere i et aktivt vekselvirkningsforhold med partiet, selvom den heller ikke har udviklet sig til et brud med partict - og slet ikke med reformismen som helhed. Endelig er reformismens tag i dens egen nye basis fra 1960'erne - de nye mellemlag - svigtende først og fremmest på grund af en voksende tvivl om den reformistiske udviklingsmodel som sådan. $\ll^{84}$

Der eksisterer altså i dag - iflg. Finnemann - et tomrum. I spørgsmålet om, hvordan dette tomrum skal udnyttes - dvs. Socialdemokratiet detroniseres af et »revolutionært parti « - bliver den anden hovedingrediens aktuel:

»Et virkelig masseopbrud fra Socialdemokratiet kan (...) kun ske hvis der (...) sker virkelige radikale omvæltninger af styrkeforholdet til arbejderklassens fordel, forbundet med eksistens af et revolutionært parti med virkelig alternativ politik og praksis. ${ }^{85}$ Ændringerne i »styrkeforholdene « har Finnemann - omend ud fra en anden opfattelse af denne ændrings karakter end KF - påvist. Men hvad skal partiet med den »virkelig alternative politik og praksis « byde på? Svaret får vi i opfattelsen af kapitalismens grundmodsætninger og kriseårsag. Denne grundmodsætning står - iflg. Finnemann mellem kapitalen som subsumtionslogik og den indre og ydre natur (jeg har andetsteds kritiseret denne krisekonception - som jeg dér kalder »den kvalitative disproportionalitetskriseteori «- mere detaljeret. ${ }^{86}$ Denne modsætning er angiveligt i dag spidset til: »Det nye er, at en række af de »avancerede « produktivkræfter i deres normale udfoldelse har en destruktiv effekt af irre-

82. Ibid. s. $22 \mathrm{f}$.

83. Ibid. s. 23.

84. Ibid. s. 32.

85. KF/RSF: Diskussionsbulletin. op.cit.

86. Lars Qvortrup: Den kapitalistiske krise ... op.cit. 
versibel karakter i forhold til naturgrundlaget (hertil hører også den menneskelige arbejdskraft selv) $\ll .87$

Her har »det »revolutionære venstre « sin chance. Indtil i dag har Socialdemokratiets reform-arbejde indfriet vælgernes behov. Men på baggrund af den påståede skærpede kvalitative disproportionalitet er der »i arbejderklassen som i de nye mellemlag (...) ved at udkrystallisere sig ny klasseinteresser « ${ }^{88}$ som Socialdemokratiet tilsyneladende ikke kan indfri - Her må »det nye venstre « træde til! Her har vi den rationelle kerne i slagordet om »kommunismens aktualitet $\ll$.

Lad mig kort fremhæve de vigtigste problemer i den anførte forklaring på reformismen og i dens strategiske konsekvenser:

For det første leverer forklaringen ikke nogen indholdsbestemmelse af reformismen: De faktorer som indgår i »magt-parallelogrammerne « er karakteriseret rent kvantitativt (som »store«, »små«, »fredsommelige «, »svage« etc.). Umiddelbart ser forklaringsmodellen nem ud. Men spørgsmålet melder sig: Hvad får disse samfundsmæssige magtdiagrammer til at ændre struktur og indhold? Finnemann skyder selv problemet til side ved at operere med uforklarede kræfter som »mellemlagenes voksende tvivl« osv., altså immanente kvalitative og udviklingsskabende kræfter, hvis udspring ikke forklares.

For det andet eksemplificerer forklaringen et vigtigt problem i den $\gg$ overenskomst « mellem »det revolutionære venstre « og arbejderklassen, som Mattick advarede mod og som »partiet« som anført finder det nødvendigt (for arbejderne!) at gennemføre. Hvorfor er der i dag det hævdede sammenfald mellem massernes »nye behov« og venstrefløjens opfattelse af samfundsmæssige antagonismer? Skyldes det at masserne har udviklet behov, der svarer til dem, som Marcuse lancerede for 10 år siden? Eller skyldes det, at der - foreløbig i analyserne - lægges behov ned over masserne, som stammer fra »den revolutionære venstrefløj«? I så fald er Mattick's advarsel mod det anmassende $»$ revolutionære parti med den virkelig alternative politik og praksis«, der skal »præge kampene«, igen aktuel: »... lige pludselig begynder teoretikerne (...) at indprente (arbejderklassen) deres egne videnskabelige begreber, at give den en strategi. Og indtil nu har vi kun set at denne intelligens, som giver arbejderklassen dens strategier, altid kun har givet arbejderklassen en strategi, der var i intelligensen som socialgruppe's egen specifikke interesse. ${ }^{89}$

87. Finnemann op.cit. s. 31.

88. Ibid. s. 29.

89. Jvf. denne artikel s. $118 \mathrm{f}$. 


\section{Arbejderklassen, fagforeningerne og Socialdemokratiet i »Fremtidens Danmark«}

Jeg har forsøgt at vise, at der fælles for VS og KF findes en opfattelse af socialdemokratismen, der for det meste ikke udtrykkes eksplicit, men kun eksisterer latent i disse partiers praksis. Denne opfattelse går ud på, at SD og arbejderklassen opfattes som relativt selvstændige størrelser: Forbindelsen mellem dem er den rent udvendige, at de reformistiske arbejdere er blevet reformistiske p.gr.a. partiets indflydelse - og at det derfor er venstrefløjens opgave på den ene eller anden måde at rive arbejderklassen ud af dette ubehagelige favntag. Jeg vil nu fremdrage et eksplicit udtryk herfor: VS's Fremtidens Danmark - et socialdemokratisk kriseprojekt fra LO og Metal. Fagbevagelse og fagopposition $i$ 70' erne. $^{90}$

Analysen af Socialdemokratiet har følgende intentionelle udgangspunkt: »Socialdemokratiet er vokset ud af arbejderklassens kamp mod virkningerne af det kapitalistiske system, af kampen for bedre lønforhold, mod arbejdsløshed, af kampen for ordentlige boligforhold, for indflydelse på samfundsudviklingen osv. ${ }^{91}$ Tilsyneladende er SD her opfattet som institutionaliseringen af den kapitalistiske arbejderklasses reproduktive praksis, hvis rødder iflg. bogen må søges »i selve kapitalismens enhed af tilsløring og afsløring af sine egne grundtræk. $\ll^{92}$

Lige så snart bogen går i gang med sin analyse af Socialdemokratiet svigtes disse intentioner imidlertid. Nu er socialdemokratismen ikke længere en selv- og samfundsforståelse for arbejderklassen i det kapitalistiske samfund, som danner grundlag for denne klasses praktiske væren og som - evt. med visse modifikationer - sammenfattes af og inkarneres i SD. Tværtimod opfattes arbejderen som en simpel homo oeconomicus, hvis praksisgrundlag er behovet for hver dag at få brød og pølse på bordet. Heroverfor står SD: Dette parti tilfredsstiller dette behov hos arbejderne (fordi de udgør dets vælger- og dermed eksistensgrundlag) eller giver i det mindste indtryk af at gøre det. Og så længe eksisterer reformismen, thi reformismen som ideologi er dels en størrelse, som SD indpoder i arbejdernes hoveder, dels en størrelse, som bestemmer SD's politiske strategi.

90. Bjørn Meidell, Niels Aagaard og Bjørn Elm: »Fremtidens Danmark - et socialdemokratisk kriseprojekt fra LO og Metal. Fagbevagelse og fagopposition i 70'erne, Bind I. VS-Forlaget, København 1978.

91. Ibid. s. 22.

92. Ibid. s. 23. 
Forholdet mellem arbejderklasse og SD skildres i overensstemmelse hermed således: »Opgøret og modstanden mod kapitalen skyldes et krav om at få tilfredsstillet en række behov. (...) Arbejderklassen støtter Socialdemokratiet så længe, det er i stand til at indfri nogle af disse behov.« Men hvorfor er bruddet så ikke sket for længst? Fordi SD på lumskelig vis for at holde på sit vælgergrundlag har bildt de naive arbejdere ting og sager ind: i de perioder, hvor SD ikke har kunnet »gennemtvinge nye reformer (...) har partiet forstået at legitimere manglen på reformer - det skyldes krisen, det skyldes faren for fascismen, det skyldes manglende parlamentariske muligheder for at komme igennem med den socialdemokratiske politik osv. Og så længe partiet kan få arbejderklassen til at tro på, at de omend ikke lige i øjeblikket så inden for en overskuelig fremtid både kan og vil gennemføre nye reformer, sålænge vil faren for større brudflader være begrænset. « ${ }^{93}$

SD skal altså forstås som et »samfundsmæssigt fænomen « (omend det som skildret er uklart, hvordan! Tilsyneladende opfattes det snarere som en organisation, som er indpodet med og derfor handler efter og udspyr en bestemt ideologi). »Derfor« (hvorfor?) skal venstrefløjen ikke gøre sig illusioner om SD.

Det skal man derimod om fagforeningen. Thi fagforeningen skal tilsyneladende ikke opfattes som et samfundsmæssigt produkt, men som den generaliserede sammenfatning af og repræsentation for den simple homo-oeconomicusarbejder. I modsætning til SD er fagforeningen ikke iflg. bogen en kapitalistisk arbejderorganisering; den slås for mad på bordet, og det gør den i princippet uden hensyn til de grænser for denne kamp, som de samfundsmæssige omstændigheder sætter.

Som sammenfatning af arbejderne som simple stimulus-responsevæsner er fagforeningen selv fri for bevidsthed (ud over den, der er forbundet med stimulus-response-aktiviteten: giv og tag). Den samfundsforståelse som fagforeningen på trods heraf har stammer ikke fra dens kapitalistiske praksis, men er indpodet fra: SD! Dette er ganske enkelt sket pr. infiltration, v.hj. af indsættelse af »socialdemokratiske fagforeningsledere « ${ }^{94}$ Forklaringen på fagforeningernes århundredlange kapital-reproduktive praksis er således SD's fremmedbestemmelse: indpodning af ideologi. Dette udtrykker sig i en mekanisk henvisning til SD, når fagforeningsmæssige aktiviteter skal forklares, en henvisning der efterhånden bliver så automatisk, at det sammenfattes i det besynderlige udtryk: »Den socialdemokratiske fagforening « -

93. Ibid. s. 26.

94. Ibid. s. 28. Se også forklaringen på tendensen i Metal, s. 413. 
én samfundsmæssig institution forklares ved hjælp af en anden: et klassisk magtsociologisk trick. ${ }^{95}$

SD bliver herved til et abstrakt organisatorisk hylster med et indlagt ideologisk handlingsmønster og et rent udvendigt forhold til arbejderen, denne ideologiløse, primitivt pragmatiske homo oeconomicus. SD er reduceret til en organisation, som p.gr.af en ond og uforklarlig egenvilje søger at forråde den arbejderklasse, som partiet af navn repræsenterer.

Op gennem det 20. århundrede bliver SD's politiske praksis for forfatterne stadig mere klart bestemt af ét hensyn: ønsket om at fastholde grebet $\mathrm{i}$ arbejderklassen. Alene dette hensyn har - iflg. bogen - bestemt forsøget på at etablere industriforbund, genoplivningen og udbygningen af fællesorganisationerne, opprioriteringen af arbejdsmarkedsnævnene og - især - byrokratiseringen af fagbevægelsen og forsøgene på at indføre ØD. Alle disse elementer skal forstås som forsøg på at »stimulere en socialdemokratisk ideologi i primært fagbevægelsens basis og lokalområderne«, som »middel til integrering af fagbevægelsen i et tættere samarbejde med arbejdsgiverne og repræsentanter for statsmagten « etc. etc. ${ }^{96}$

Hvordan forklarer man, at denne bedrageri-historie er gået godt så længe? For det første skyldes det den allerede omtalte infiltration. For det andet skyldes det »gammel vane « og dårlige konventioner: »Egteskabet mellem LO og Socialdemokratiet er langt og prøvet og sandsynligheden for et brud på dette tidspunkt er mindre end minimale. $\ll^{97}$

Men først og fremmest skyldes det (selvfølgelig), at der ikke har eksisteret noget alternativ til SD, et udefrakommende parti der kunne tilbyde vores simple homo oeconomicus et andet ståsted med bedre betingelser for sul på frokostbordet. Her har vi venstrefløjens mission, hvilket KF præcist har fået fat på: »Masser af reformistisk indstillede arbejdere vil (...) kunne gå med i den socialistiske reformkamp, simpelthen fordi den opstiller de mest rimelige, offensive og lovende perspektiver for kampen mod borgerskabet (vurderet $i$ forhold til de фvrige arbejderpartiers bud). $«^{98}$

95. $\gg \ldots$ den socialdemokratiske fagbevægelse.« (s. 46) Den oprindelige tanke med industriforbund - nemlig at styrke arbejderklassen - er »i dag »omfunktioneret« af den socialdemokratiske fagbevægelse: Meningen er nu ikke længere at styrke arbejdspladsernes kamp. Meningen er primært at styrke fagbureaukratiets magt over de nedre dele af fagbevægelsen for derved at hindre oppositionsdannelser og udskred mod venstre.« S. 73 får vi en variant af ordmagien: »Socialdemokratiet som fagbevægelse og statsbærende parti«. S. 98 tales der i forklarende $\varnothing$ jemed om »socialdemokratiet i fagbevægelsen ...« Osv.

96. Ibid. s. 125 og s. 84 .

97. Ibid. s. 40.

98. Klavs Birkholm: »En revolutionær reformstrategi« op.cit. s. 27. 
Venstrefløjen skal således blot med gode løfter lokke arbejderne til venstre. Thi »der er to hovedfarer for et parti som Socialdemokratiet. På den ene side af miste grebet om arbejderklassen, og på den anden side at havne i åben konfrontation med borgerskabet. « ${ }^{99}$ I den magtsociologiske forestillingsverden er opgaven således simpel: Vi trækker arbejderne lidt længere herudaf, og SD går på røven.

Denne kamp for at rive arbejderklassen ud af kløerne på SD - og over i de akademiske statsbyrokraters statskapitalistiske lyksaligheder - sker, som vi allerede har set, enten ved indsmigring hos arbejderne eller ved delegitimering af SD. Under begge omstændigheder kan bestræbelserne forenes med infiltration i (de værdifri) fagforeninger: Dette er helt igennem en bekræftelse af den klassiske leninistiske tankegang: ${ }^{100}$ arbejderen er et vane-væsen, hvis aktiviteter bestemmes af, hvilken organisatorisk vilje han/hun er underlagt. Klassekampen er partiernes kamp om sjæle. Midlet er overbud. Og perspektivet er (i bedste fald) en statskapitalistisk fastholdelse af lønarbejdet - med »socialismen« som det nye ideologiske integrationsnummer.

99. Bjørn Meidell et.al. op.cit. s. 35.

100. I det mindste således som han udtrykker sig i »Venstrekommunismen « - en børnesygdom. Kbh. 1977. 


\section{TIDSSKRIFTET KURASJE}

\section{KURASJE 17}

148 sider. Kr. 35,00

Indhold:

Indkomstpolitik og kapitalakkumulation i Danmark af Bredsdorff, Brinch og Hansen.

Økonomisk krise, massearbejdsløshed og globalstyring af Semmler og Hoffmann.

Statsfunktioner og reproduktion af arbejdskraft af Finn Hansson.

Hvad skal vi med kapitallogikken? af Jens Henning Rasmussen.

Miljøanlæg og værdicirkulation af Erling Jelsøe.

\section{KURASJE 18}

168 sider. Kr. 45,00

Indhold:

Fagbevægelsens krisestrategi og den statslige indkomstpolitik af Bredsdorff, Holm og Søndergaard.

Kriseudviklingen i Danmark af Arne Kurdahl.

Den statslige arbejdsmarkedspolitik i krisen af Bo Elling Nielsen.

Fagbevægelsens lonpolitik af Erling Havn.

Typografarbejde af Andersson og Sondergaard.

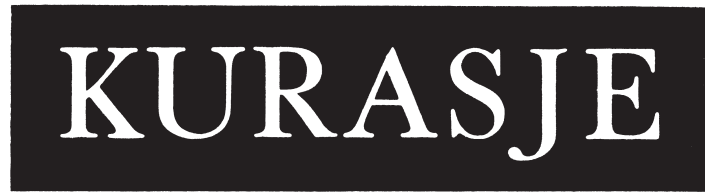

